\title{
Neurogliaform Neurons Form a Novel Inhibitory Network in the Hippocampal CA1 Area
}

\author{
Christopher J. Price, ${ }^{1}$ Bruno Cauli, ${ }^{2}$ Endre R. Kovacs, ${ }^{1}$ Akos Kulik, ${ }^{3}$ Bertrand Lambolez, ${ }^{2}$ Ryuichi Shigemoto, ${ }^{4,5}$ and \\ Marco Capogna ${ }^{1}$ \\ ${ }^{1}$ Medical Research Council, Anatomical Neuropharmacology Unit, Oxford OX1 3TH, United Kingdom, ${ }^{2}$ Laboratoire de Neurobiologie et Diversite Cellulaire, \\ Centre National de la Recherche Scientifique, Ecole Superieure de Physique et Chime Industrielles de la ville de Paris, 75005 Paris, France, ${ }^{3}$ Department of \\ Anatomy and Cell Biology, University of Freiburg, 79104 Freiburg, Germany, ${ }^{4}$ Division of Cerebral Structure, National Institute for Physiological Sciences, \\ Okazaki 444-8787, Japan, and ${ }^{5}$ Solution Oriented Research for Science and Technology, Japan Science and Technology Corporation, Kawaguchi 332-0012, \\ Japan
}

We studied neurogliaform neurons in the stratum lacunosum moleculare of the CA1 hippocampal area. These interneurons have short stellate dendrites and an extensive axonal arbor mainly located in the stratum lacunosum moleculare. Single-cell reverse transcriptionPCR showed that these neurons were GABAergic and that the majority expressed mRNA for neuropeptide Y. Most neurogliaform neurons tested were immunoreactive for $\alpha$-actinin-2, and many stratum lacunosum moleculare interneurons coexpressed $\alpha$-actinin-2 and neuropeptide Y. Neurogliaform neurons received monosynaptic, DNQX-sensitive excitatory input from the perforant path, and $40 \mathrm{~Hz}$ stimulation of this input evoked EPSCs displaying either depression or initial facilitation, followed by depression. Paired recordings performed between neurogliaform neurons showed that $85 \%$ of pairs were electrically connected and $70 \%$ were also connected via GABAergic synapses. Injection of sine waveforms into neurons during paired recordings resulted in transmission of the waveforms through the electrical synapse. Unitary IPSCs recorded from neurogliaform pairs readily fatigued, had a slow decay, and had a strong depression of the synaptic response at a $5 \mathrm{~Hz}$ stimulation frequency that was antagonized by the GABA $\mathrm{B}_{\mathrm{B}}$ antagonist $(2 S)-3-[[(1 S)-1-(3,4-$ dichlorophenyl)ethyl]amino-2-hydroxypropyl](phenylmethyl) phosphinic acid (CGP55845). The amplitude of the first IPSC during the $5 \mathrm{~Hz}$ stimulation was also increased by CGP55845, suggesting a tonic inhibition of synaptic transmission. A small unitary $\mathrm{GABA}_{\mathrm{B}}$ mediated IPSC could also be detected, providing the first evidence for such a component between GABAergic interneurons. Electron microscopic localization of the $\mathrm{GABA}_{\mathrm{B} 1}$ subunit at neurogliaform synapses revealed the protein in both presynaptic and postsynaptic membranes. Our data disclose a novel interneuronal network well suited for modulating the flow of information between the entorhinal cortex and CA1 hippocampus.

Key words: unitary IPSCs; electrical synapses; interneuron; $\mathrm{GABA}_{\mathrm{B}}$; perforant path; short-term plasticity

\section{Introduction}

The entorhinal cortex and hippocampus are two structures highly interconnected and constitute an important neural ensemble involved in several brain activities. Correlated theta and gamma oscillations are detected in both the hippocampus and entorhinal cortex in vivo (Buzsaki, 2002), and these two structures play key roles in the establishment of place fields as well as

\footnotetext{
Received Dec. 14, 2004; revised May 18, 2005; accepted June 6, 2005.

This work was supported by the Medical Research Council (United Kingdom). We thank Prof. Peter Somogyi for help with immunocytochemistry and microscopy and for critical reading of a previous version of this manuscript, Prof. Jean Rossier for help, and Angharad Thomas and Theofanis Karayannis for discussions and comments on this manuscript. We also thank Dr. Yannis Dalezios, Romana Hauer, Dr. Laszlo Marton, Ben Micklem, David Roberts, Hélène Geoffroy, Ulrich Nöller, and Aniko Schneider for technical aid and expertise.

Correspondence should be addressed to Dr. Marco Capogna, Medical Research Council, Anatomical Neuropharmacology Unit, Mansfield Road, 0xford 0X1 3TH, UK. E-mail: marco.capogna@pharm.ox.ac.uk.

E. R. Kovacs' present address: Veterinary Medical Research Institute, Hungarian Academy of Sciences, H-1143 Budapest, Hungary.

B. Lambolez's present address: NPA, Centre National de la Recherche Scientifique Unité Mixte de Recherche 7102, Université Paris VI, 75005 Paris, France.

D0I:10.1523/JNEUROSCI.1135-05.2005

Copyright (C) 2005 Society for Neuroscience $\quad$ 0270-6474/05/256775-12\$15.00/0
}

during memory and cognitive tasks (Sybirska et al., 2000; Brun et al., 2002). Furthermore, they are involved in many neurological disorders, including temporal lobe epilepsy and Alzheimer's disease (Braak and Braak, 1993; Avoli et al., 2002).

The stratum lacunosum moleculare (SLM) of the hippocampus is the main site of termination of axons from layer III of the entorhinal cortex that forms the direct excitatory perforant path input to the CA1 region (Witter et al., 1988; Gloveli et al., 1997). In this layer, type I synapses have been observed between axons from the entorhinal cortex terminating on dendritic spines of pyramidal cells and also on parvalbumin-immunoreactive dendrites of GABAergic interneurons (Desmond et al., 1994; Kiss et al., 1996). Consistent with the anatomical data, stimulation of the perforant path has been shown to monosynaptically excite the CA1 pyramidal cell (Yeckel and Berger, 1990; Capogna, 2004). However, it also leads to a profound inhibition of pyramidal cells, most likely through activation of feedforward GABAergic interneurons that have dendrites located in the SLM (Empson and Heinemann, 1995; Remondes and Schuman, 2002).

Interneurons in the SLM have been investigated thoroughly 
(Lacaille and Schwartzkroin, 1988; Williams and Lacaille, 1992; Williams et al., 1994; Khazipov et al., 1995; Spruston et al., 1997; Bertrand and Lacaille, 2001). These interneurons represent a heterogeneous population of cells, belonging to several classes (Freund and Buzsaki, 1996; McBain and Fisahn, 2001; Maccaferri and Lacaille, 2003; Somogyi and Klausberger, 2005). The stimulation of SLM interneurons evokes in pyramidal cells a $\mathrm{GABA}_{\mathrm{A}}$ receptor-mediated unitary IPSP with a slow rise time and decay, consistent with the projection of these interneurons exclusively to dendritic regions of the pyramidal neuron (Vida et al., 1998). Interestingly, tonic presynaptic $\mathrm{GABA}_{\mathrm{B}}$ inhibition of the unitary IPSP has been observed in some but not all SLM-pyramidal cell connections (Ouardouz and Lacaille, 1997; Bertrand and Lacaille, 2001). However, simultaneous release of GABA from several interneurons is usually required for the spillover of GABA and activation of $\mathrm{GABA}_{\mathrm{B}}$ receptors at hippocampal synapses (Scanziani, 2000).

In the present study, we have identified a novel network of electrically and chemically connected neurons in the SLM of area CA1 formed by a specific interneuron type, the so-called neurogliaform (NG) cell (Ramon y Cajal, 1911). We found that unitary inhibitory responses between NG cells are subjected to substantial $\mathrm{GABA}_{\mathrm{B}}$ receptor-mediated modulation. The location of NG cells in the SLM and the high density of axons that they provide to this layer suggest that these interneurons play a modulatory role on the input from the perforant path into the CA1.

\section{Materials and Methods}

Slice preparation. All procedures involving animals were performed using methods approved by the United Kingdom Home Office and in accordance with The Animals (Scientific Procedures) Act, 1986. Juvenile Sprague Dawley rats (Charles River, Margate, UK) between 12 and $21 \mathrm{~d}$ old were anesthetized with isoflurane and decapitated. The brain was removed quickly, extra tissue was trimmed away, and the remaining block containing the hippocampus was mounted for vibratome sectioning in ice-cold artificial CSF (ACSF) containing the following (in $\mathrm{mm}$ ): $130 \mathrm{NaCl}, 3.5 \mathrm{KCl}, 2.5 \mathrm{CaCl}_{2}, 1.5 \mathrm{MgSO}_{4}, 1.25 \mathrm{NaH}_{2} \mathrm{PO}_{4}, 24 \mathrm{NaHCO}_{3}$, and 10 glucose, saturated with $95 \% \mathrm{O}_{2}$ and $5 \% \mathrm{CO}_{2}$, to which $3 \mathrm{~mm}$ kynurenic acid was added. Horizontal sections $(300-320 \mu \mathrm{m})$ were made consisting of the dorsal hippocampus and attached entorhinal cortex, which were allowed to recover in ACSF at room temperature, but without added kynurenic acid, for at least $45 \mathrm{~min}$ before recording. $\mathrm{Al}-$ ternatively, a high-sucrose/high-magnesium solution (in mм: $87 \mathrm{NaCl}$, $25 \mathrm{NaHCO}_{3}, 25$ glucose, 75 sucrose, $2.5 \mathrm{KCl}, 1.25 \mathrm{NaH}_{2} \mathrm{PO}_{4}, 0.5 \mathrm{CaCl}_{2}$, and $7 \mathrm{MgCl}_{2}$ ) was also used for slice preparation.

Whole-cell recording and analysis. Single-cell and paired whole-cell recordings were performed using an EPC9/2 amplifier (HEKA, Lambrecht, Germany). Slices were placed in a recording chamber, superfused constantly with ACSF, and maintained at a temperature of $30-35^{\circ} \mathrm{C}$. Fifty micromolars of the $\mathrm{GABA}_{\mathrm{A}}$ receptor antagonist picrotoxin were added to the ACSF to isolate evoked glutamatergic responses. NG cells in the CA1 SLM were visually identified based on soma shape and size. Recording electrodes were filled with (in mM) $126 \mathrm{~K}$-gluconate, 10 HEPES, 10 $\mathrm{Na}_{2}$ Phosphocreatine, $4 \mathrm{KCl}, 4 \mathrm{Mg}$-ATP, $0.3 \mathrm{Na}-\mathrm{GTP}$, and $0.5 \%$ biocytin, $\mathrm{pH} 7.3$ with $\mathrm{KOH}$, and had resistances between 3 and $7 \mathrm{M} \Omega$. In a few experiments, a cesium-based intracellular solution was used (in $\mathrm{mM}$ ): 126 Cs-methansulfonate, $4 \mathrm{CsCl}, 10 \mathrm{HEPES}, 10 \mathrm{Na}_{2}$ Phosphocreatine, $4 \mathrm{Mg}$ ATP, $0.3 \mathrm{Na}-\mathrm{GTP}$, and $0.5 \%$ biocytin, $\mathrm{pH} 7.3$ with $\mathrm{CsOH}$. Neurons were voltage clamped at a holding potential of $-70 \mathrm{mV}$, with the exception of postsynaptic neurons during paired recordings, which were held at -50 $\mathrm{mV}$ to enhance the size of GABAergic responses. EPSCs were evoked from the direct perforant pathway to the CA1 using either a tungsten concentric bipolar electrode or monopolar electrode inserted close to the presubiculum. To avoid possible recruitment of the hippocampal trisynaptic pathway, the CA3 region of the hippocampus was dissected away, leaving the entorhinal cortex, dentate gyrus CA1, and subiculum (Emp- son and Heinemann, 1995). However, we cannot rule out the possibility that signals may have arisen from fibers that originated in the thalamic nucleus reunions or amygdala that send axons to the SLM (Amaral and Witter, 1995). Series resistance compensation was not used during recording; however, access resistance was always monitored.

Data were analyzed off-line using Pulsefit (HEKA) and IGOR Pro (WaveMetrics, Lake Oswego, OR) for synaptic responses. To facilitate the measurement of onset latencies for evoked EPSCs, traces were differentiated in IGOR Pro, and the time from the start of the stimulation artifact to the first point below the baseline on the differentiated EPSC was measured. Synaptic jitter was calculated as the SD of the mean latency. Kinetic analysis and exponential fitting of synaptic responses were also performed in IGOR Pro. For the analysis of action potential halfwidth and afterhyperpolarizing potential (AHP) amplitude, the first action potential to be evoked using a minimum amount of depolarization was used for this purpose. Input resistances were obtained from the slope of the linear portion of voltage/current plots.

Statistical tests and analyses were performed using PRISM (GraphPad, San Diego, CA). Statistical tests of the data, unless noted otherwise, were compared via one-way ANOVA. If required, the Bonferroni's multiple comparisons post hoc test was used to compare means between selected pairs of data. Unless indicated otherwise, values presented here and in the figures represent the mean $\pm \mathrm{SD}$.

Single-cell reverse transcription-PCR. Cytoplasm harvesting of the recorded neurons and reverse transcription (RT) were performed as described previously (Lambolez et al., 1992). Patch pipettes were filled with $8 \mu \mathrm{l}$ of internal solution containing the following: $144 \mathrm{~mm} \mathrm{~K}$-gluconate, 3 mM MgCl2, 0.5 mm EGTA, $10 \mathrm{~mm}$ HEPES, and $2 \mathrm{mg} / \mathrm{ml}$ biocytin. The $\mathrm{pH}$ was adjusted to 7.2, and osmolarity was adjusted to 285/295 mOsm. At the end of the recording, as much as possible of the cell contents was aspirated into the recording pipette by application of a gentle negative pressure while maintaining the tight seal. The pipette was then delicately removed to allow outside-out patch formation. Next, the contents of the pipette were expelled into a test tube and RT was performed in a final volume of $10 \mu$ l. Two steps of multiplex PCR were performed essentially as described previously (Cauli et al., 1997). The cDNAs present in the 10 $\mu \mathrm{l}$ T reaction were first amplified simultaneously using all of the primer pairs described in Table 1 (for each primer pair, the sense and antisense primers were positioned on two different exons). Taq polymerase (2.5 U; Qiagen, Hilden, Germany) and 20 pmol of each primer were added to the buffer supplied by the manufacturer (final volume, $100 \mu \mathrm{l}$ ), and 20 cycles $\left(94^{\circ} \mathrm{C}, 30 \mathrm{~s} ; 60^{\circ} \mathrm{C}, 30 \mathrm{~s} ; 72^{\circ} \mathrm{C}, 35 \mathrm{~s}\right.$ ) of PCR were run. Second rounds of PCR were then performed using $2 \mu \mathrm{l}$ of the first PCR product as a template. In this second round, each cDNA was amplified individually using its specific nested primer pair (Table 1) by performing 35 PCR cycles (as described above). Ten microliters of each individual PCR were then run on a $1.5 \%$ agarose gel using $\phi \mathrm{x} 174$ digested by HaeIII as a molecular weight marker and stained with ethidium bromide.

Cell reconstruction and immunocytochemistry. To verify the identity of recorded neurons, cells were filled with biocytin and processed to reveal their dendritic and axonal patterns. After recording, cells were fixed immediately for at least $24 \mathrm{~h}$ by immersion in $4 \%$ paraformaldehyde and $15 \%$ saturated (v/v) picric acid $(\sim 0.2 \%)$ in $0.1 \mathrm{~m}$ phosphate buffer $(\mathrm{PB})$, $\mathrm{pH}$ 7.4. Slices were resectioned using a vibratome at $60 \mathrm{~mm}$ after being embedded in gelatin. Biocytin was then visualized with diaminobenzidine using the Vector ABC kit (Vector Laboratories, Burlingame, CA) and intensified with osmium tetroxide. Neurons were later drawn at $63 \times$ (dendrites) and $100 \times$ (axons) using a drawing tube. In addition to reconstruction, some slices were used for immunocytochemical experiments. After blocking nonspecific antibody binding in Tris buffer with $10 \%$ normal goat serum (NGS) for $1 \mathrm{~h}$, sections (60 $\mu \mathrm{m}$ thickness) were incubated in a mouse antibody to $\alpha$-actinin-2 (dilution, 1:300; clone EA-53; Sigma, St. Louis, MO) for $\sim 48 \mathrm{~h}$ at $4^{\circ} \mathrm{C}$. Afterward, slices were incubated in a mixture of goat anti-mouse fluorescein-conjugated antibody plus aminomethylcoumarin acetate (AMCA)-conjugated streptavidin (dilutions, 1:1000; both from Vector Laboratories) for $2 \mathrm{~h}$. Sections were then washed and mounted in Vectashield (Vector Laboratories) before viewing. In addition to the resectioned slices from whole-cell recording experiments, sections from the brain of a rat perfused with the 
Table 1. Primers used for multiplexed RT-PCR

\begin{tabular}{|c|c|c|c|}
\hline Gene & First PCR primers & Second PCR nested primers & Size (br \\
\hline \multirow[t]{2}{*}{ GAD 65 (\#M72422) } & Sense, 713: TCTTTTCTCCTGGTGGTGCC & Sense, 743: TGTACGCCATGCTCATTGCC & \\
\hline & Antisense, 1085: CCCCAAGCAGCATCCACAT & Antisense, 1032: CAGCTACAGCCAAGAGAGGATCA & 312 \\
\hline \multirow[t]{2}{*}{ GAD 67 (\#M76177) } & Sense, 529: TACGGGGTTCGCACAGGTC & Sense, 581: TGGATATCATTGGTTTAGCTGGC & \\
\hline & Antisense, 1110: CCCCAAGCAGCATCCACAT & Antisense, 1066: TCACATATGTCTGCAATCTCCTGG & 509 \\
\hline \multirow[t]{2}{*}{ b-NOS (\#X59949) } & Sense, 2714: AACTGGGAGGGGAGAGGATTC & Sense, 2727: GAGGATTCTGAAGATGAGGGAGG & \\
\hline & Antisense, 3242: GGGTGGGAGGCGAGATTCAT & Antisense, 3219: CCTTCCAATTACTGATGACACCC & 515 \\
\hline \multirow[t]{2}{*}{ CB (\#M27839) } & Sense, 134: AGGCACGAAAGAAGGCTGGAT & Sense, 165: CCTGAGATGAAAACCTTTGTGG & \\
\hline & Antisense, 544:TCCCACACATTTTGATTCCCTG & Antisense, 391: CACGGTCTTGTTTGCTTTCTCTA & 249 \\
\hline \multirow[t]{2}{*}{ PV (\#M12725) } & Sense, 247: ACAAAGACGCTGATGGCTGC & Sense, 259: ATGGCTGCTGGAGACAAGGA & \\
\hline & Antisense, 607: CGTGGTCCTTCGCTCTCTCTC & Antisense, 577: TCTACTATACCCCCACTGCTGTCC & 342 \\
\hline \multirow[t]{2}{*}{ CR (\#X66974) } & Sense, 142: CTGGAGAAGGCAAGGAAAGGT & Sense, 157: AAAGGTTCTGGCATGATGTCC & \\
\hline & Antisense, 429: AGGTTCATCATAGGGACGGTTG & Antisense, 401: TCAGGAGGTCGGACAGAAATC & 265 \\
\hline \multirow[t]{2}{*}{ NPY (\#M15880) } & Sense, $-46:$ GCCCAGAGCAGAGCACCC & Sense, -22 : CAGAGACCACAGCCCGCC & \\
\hline & Antisense, 292: CAAGTTTCATTTCCCATCACCA & Antisense, 261: TCTTCAAGCTTGTTCTGGGG & 303 \\
\hline \multirow[t]{2}{*}{ VIP (\#X02341) } & Sense, 167: TGCCTTAGCGGAGAATGACA & Sense, 186: ACGCCCTATTATGATGTGTCCAG & \\
\hline & Antisense, 434: CCTCACTGCTCCTCTTCCCA & Antisense, 380: TTTGCTTTCTAAGGCGGGTG & 214 \\
\hline \multirow[t]{2}{*}{ SOM (\#K02248) } & Sense, 43: ATCGTCCTGGCTTTGGGC & Sense, 75: GCCCTCGGACCCCAGACT & \\
\hline & Antisense, 231: GCCTCATCTCGTCCTGCTCA & Antisense, 207: TGGGGCAAATCCTCAGGC & 150 \\
\hline \multirow[t]{2}{*}{ CCK (\#K01259) } & Sense, 177: CGCACTGCTAGCCCGATACA & Sense, 192: ATACATCCAGCAGGTCCGCA & \\
\hline & Antisense, 373: TTTCTCATTCCGCCTCCTCC & Antisense, 320: TGGGTATTCGTAGTCCTCAGCAC & 151 \\
\hline \multirow[t]{2}{*}{ Dyn (\#M_019374) } & Sense, 65: ACTGCCTGTCCTTGTGTTCCCT & Sense, 91: GCAGTGAGGACGCAGGATGG & \\
\hline & Antisense, 329: GAGACGCTGGTAAGGAGTTGGC & Antisense, 311: GGCCTTTCTCCAGCTCCTTCA & 241 \\
\hline \multirow[t]{2}{*}{ Enk (\#M28263) } & Sense, 451: GCCAACTCCTCCGACCTGCT & Sense, 482: TGGGAACAGGAGACAACCGTG & \\
\hline & Antisense, 772: GCCTCCGTATCTTTTTTCCATCTC & Antisense, 734: AGTAACTTTCGCCTTCTTCATCCG & 276 \\
\hline
\end{tabular}

Position 1 is the first base of the start codon. GAD 65 and 67, Glutamic acid decarboxylases 65 and 67; CB, calbindin; PV, parvalbumin; CR, calretinin; VIP, vasointestinal peptide; SOM, somatostatin; CCK, cholecystokinin; Dyn, dynorphin; Enk, enkephalin.

same fixative as above were used as a positive control for verifying that the antibody reaction was successful. Additional triple-labeling immunocytochemical experiments were performed on sections of perfusionfixed rat brain $(n=2)$ using the monoclonal antibody to $\alpha$-actinin-2, a rabbit polyclonal antibody to neuropeptide Y (NPY; dilution, 1:1000; DiaSorin, Wokingham, UK), and a sheep polyclonal antibody to nitric oxide synthase (b-NOS; dilution, 1:500; Chemicon Europe, Chandlers Ford, UK). After the incubation in a mixture of primary antibodies, the sections were washed and incubated in a mixture of AMCA-conjugated goat anti-mouse (dilution, 1:100; Jackson ImmunoResearch, West Grove, PA), Alexa-conjugated goat anti-rabbit (dilution, 1:1000; Molecular Probes, Eugene, OR), and Cy3-conjugated rabbit anti-sheep (dilution, 1:400; Jackson ImmunoResearch) antibodies. The results from both animals were pooled because they had a similar proportion of labeled cells $\left(\chi^{2}\right.$ test; $\left.p>0.1\right)$.

Immunogold labeling of $G A B A_{B}$ receptors. An affinity-purified antibody (B17) was used that was raised against the $\mathrm{GABA}_{\mathrm{B} 1 \mathrm{a} / \mathrm{b}}$ protein recognizing two splice variants of the $\mathrm{GABA}_{\mathrm{B} 1}$ subunit. The antibody was raised in rabbits, and its characteristics and specificity have been described previously (Kulik et al., 2002). Hippocampal sections $(n=5)$ were treated for single pre-embedding immunogold labeling for the $\mathrm{GABA}_{\mathrm{B} 1}$ protein as described previously (Kulik et al., 2003). Hippocampal slices after electrophysiological recordings were processed for immunolabeling for the $\mathrm{GABA}_{\mathrm{B} 1}$ subunit and visualization of the biocytin-filled NG cells. After recordings, slices were immersed into a fixative containing $2.5 \%$ paraformaldehyde, $1.25 \%$ glutaraldehyde, and $15 \%$ saturated picric acid made up in $0.1 \mathrm{M} \mathrm{PB}, \mathrm{pH}$ 7.4. After fixation, they were rinsed in $0.1 \mathrm{M} \mathrm{PB}$ and incubated in $1 \% \mathrm{H}_{2} \mathrm{O}_{2}$. Slices were cryoprotected in $0.1 \mathrm{M} \mathrm{PB}$ containing $10 \%$ and $20 \%$ sucrose and freeze thawed in liquid nitrogen, and sections were cut on a vibratome at a thickness of $50 \mu \mathrm{m}$. They were incubated in a blocking solution containing 20\% NGS (Vector Laboratories) made up in $50 \mathrm{~mm}$ Tris-buffered saline (TBS), $\mathrm{pH} \mathrm{7.3,} \mathrm{for} 1 \mathrm{~h}$, followed by incubation with the primary antibody $(3.0 \mu \mathrm{g} / \mathrm{ml})$ for the $\mathrm{GABA}_{\mathrm{B} 1}$ subunit diluted in TBS containing $3 \%$ NGS overnight at $4^{\circ} \mathrm{C}$. After washing, the sections were incubated with $1.4 \mathrm{~nm}$ of gold-coupled goat anti-rabbit secondary antibody (1:100; Nanogold; Nanoprobes, Stony Brook, NY) made up in TBS containing $1 \%$ NGS overnight at $4^{\circ} \mathrm{C}$. It was followed by the silver enhancement of the gold particles with an HQ Silver kit (Nanoprobes). After washes in TBS, sections were subsequently incubated in the avidin-biotin-peroxidase complex (ABC Elite kit; Vector Laboratories) overnight at $4^{\circ} \mathrm{C}$ to visualize the biocytin-filled NG cells. The peroxidase labeling was revealed by using $3,3^{\prime}$-diaminobenzidine tetrahydochloride (Sigma) and $0.01 \% \mathrm{H}_{2} \mathrm{O}_{2}$. The sections were treated with $1 \%$ $\mathrm{OsO}_{4}$, washed, and contrasted in $1 \%$ uranyl-acetate. They were dehydrated and flat embedded in epoxy resin (Durcupan ACM; SigmaAldrich, Gillingham, UK). Serial ultrathin sections of the immunolabeled dendritic shafts and axon terminals of identified NG cells were cut, and the distribution of immunoparticles for the $\mathrm{GABA}_{\mathrm{B} 1}$ subunit over the synaptic and extrasynaptic membranes of those profiles was investigated.

Chemicals and drugs. All drugs were applied to the recording preparation through the bath. Salts used in the preparation of the internal recording solution and ACSF were obtained from either BDH Laboratory Supplies (Poole, UK) or Sigma. 6,7-Dinitoquinoxaline-2, 3-dione (DNQX), (-)-bicuculline methochloride, gabazine/6-imino-3-(4-methoxyphenyl)1(6H)-pyridazinebutanoic acid hydrobromide (SR95531), (2S)-3-[[(1S)1-(3,4-dichlorophenyl)ethyl] amino-2-hydroxypropyl] (penylmethyl)phosphinic acid (CGP55845), and picrotoxin were obtained from Tocris Cookson (Bristol, UK). Carbenoxolone was obtained from Sigma.

\section{Results}

\section{Dendritic and axonal patterns and molecular markers of NG} cells in the SLM

The results reported here arise from recordings from 71 single neurons and 70 pairs of neurons that had the appearance of NG cells when visualized by biocytin (Fig. $1 A, B$ ). The characteristic features of these neurons were a round cell body and short, nonspiny dendrites (Fig. $1 C_{1}$ ) that were arranged in a stellate pattern around the cell body, spatially localized to the SLM, and often entered the molecular layer of the dentate gyrus. The main stem dendrites branched profusely close to the soma, giving the dendritic field a bushy appearance. In addition, the axons of NG cells were usually recovered in horizontal slices and characteristically densely arranged and occupied a greater area than the dendrites. The main axon branched profusely close to the soma, producing a dense arbor that is a hallmark of the cell (Fig. $1 C_{2}$ ). Further- 
A

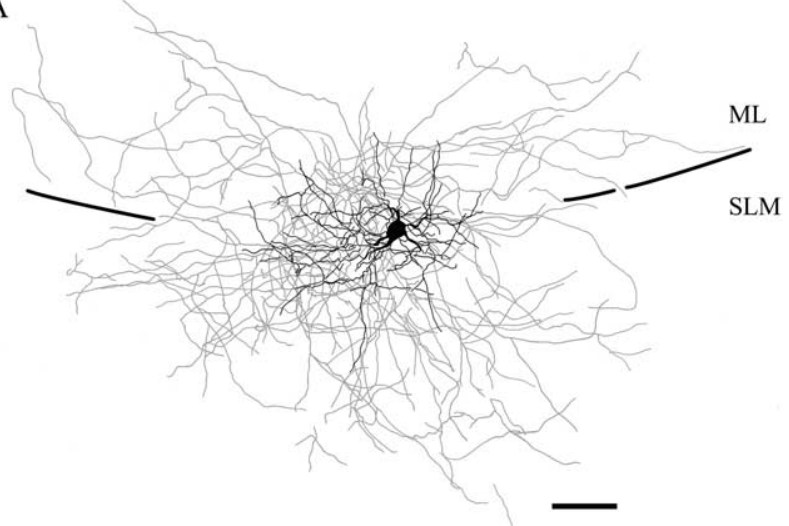

B
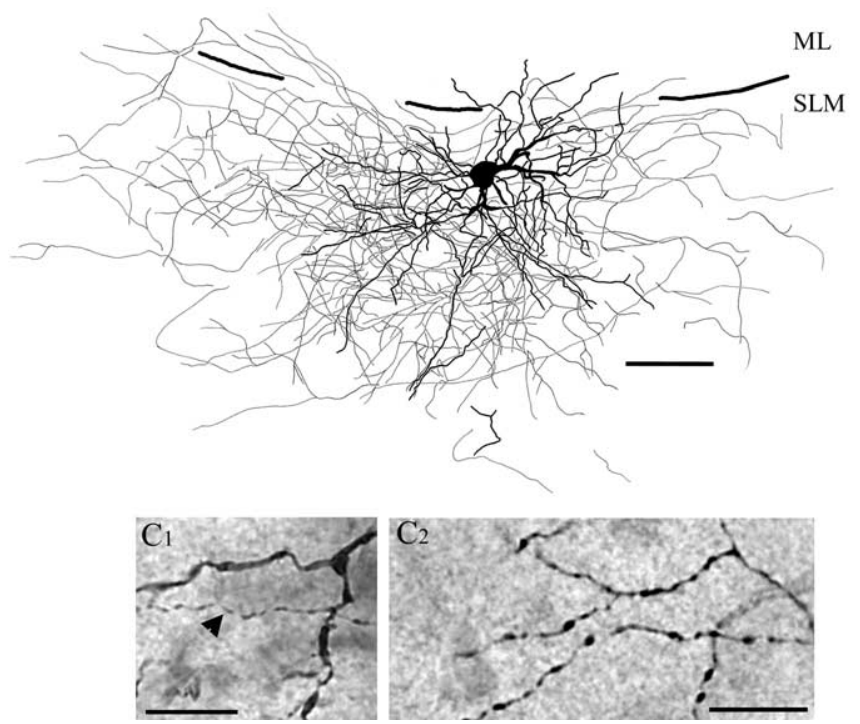

Figure 1. Reconstruction of NG cells in the SLM of area CA1. A, Reconstruction of an NG cell (P18) illustrating dendrites (black) and axons (gray). Perforant pathway stimulation at $40 \mathrm{~Hz}$ elicited EPSCs with a facilitating/depressing pattern in this cell, like the pattern shown in Figure $4 A_{2}$. Note that the dendrites and axons cross the hippocampal fissure and extend both into the molecular layer of the dentate gyrus and the SLM of area CA1. B, Reconstruction of another NG cell (P13) illustrating dendrites (black) and axons (gray). Perforant pathway stimulation at 40 $\mathrm{Hz}$ evoked EPSCs with a depressing pattern in this cell, like the pattern shown in Figure $4 A_{1}$. The dendrites and axon are mostly restricted to the CA1 SLM. SLM, Stratum lacunosum moleculare; $\mathrm{ML}$, molecular layer of the dentate gyrus. $C_{1}$, Micrograph showing detail of dendrites from a different NG cell; an axonal process is also visible and is indicated by the arrowhead. $\boldsymbol{C}_{2}$, Micrograph illustrating the detail of axonal processes showing branching points and varicosities of another NG cell. Scale bars: $\boldsymbol{A}, 50 \mu \mathrm{m} ; \boldsymbol{B}, 25 \mu \mathrm{m} ; \boldsymbol{C}_{1}, \boldsymbol{C}_{2}, 5 \mu \mathrm{m}$.

more, like the dendrites, the axons also tended to occupy mainly the SLM, often traveling fairly long distances along the SLM axis. Interestingly, cells were commonly encountered as having axon collaterals crossing into the neighboring molecular layer of the dentate gyrus.

Unlike for other interneuron types in the hippocampus, such as parvalbumin-expressing basket cells, no molecular markers have been available for NG cells. Therefore, we took advantage of the whole-cell recording configuration to harvest cytoplasm from recorded cells and perform single-cell RT-PCR, testing NG cells for expression of mRNAs for a panel of standard markers used in the identification of interneurons (Fig. 2A). All cells studied were positive for the GAD 65/67, confirming their GABAergic phenotype. Strikingly, 12 of $15 \mathrm{NG}$ cells were NPY positive, whereas only 2 of 11 non-NG interneurons expressed mRNA for this
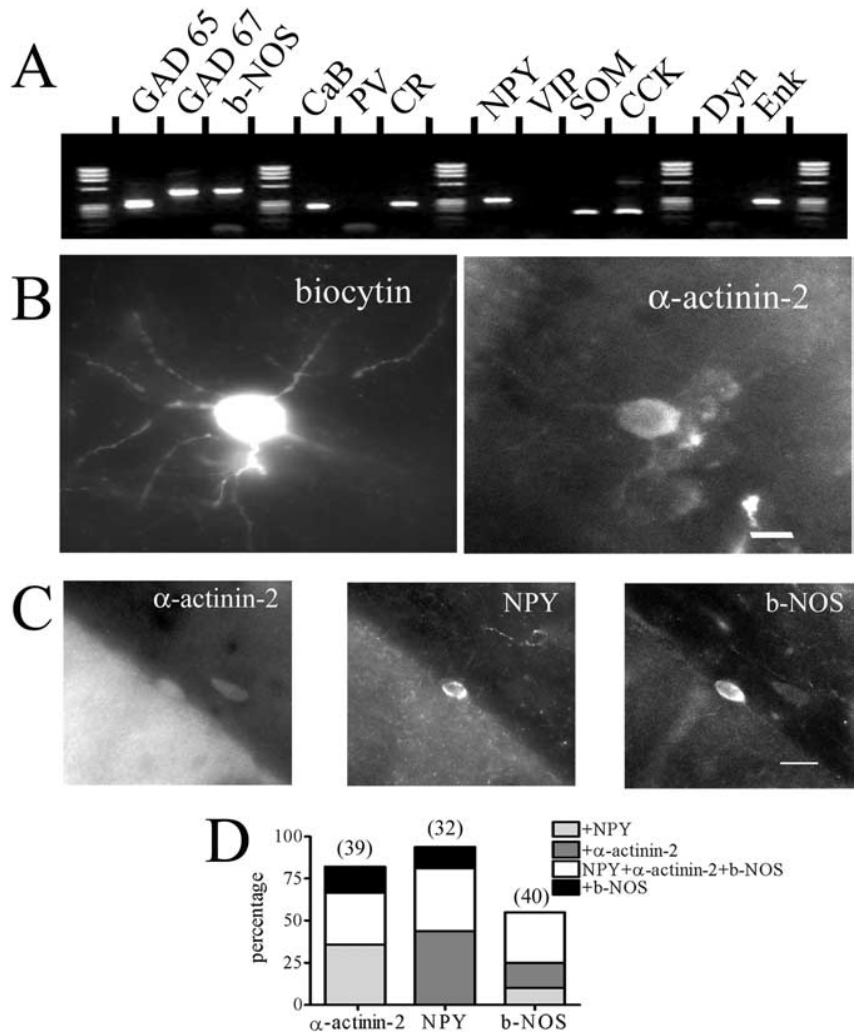

Figure 2. Molecular markers of NG cells in the SLM. $\boldsymbol{A}$, Agarose gel electrophoresis of the multiplex single-cell RT-PCR product from the neuron in Figure $1 A$ using primers to test the GABAergic, calcium-binding protein, and neuropeptide phenotypes of the neuron. GAD 65 and 67, Glutamic acid decarboxylases 65 and 67; b-NOS, nitric oxide synthase; CaB, calbindin; PV, parvalbumin; $\mathrm{CR}$, calretinin; $\mathrm{NPY}$, neuropeptide Y; VIP, vasointestinal peptide; SOM, somatostatin; CCK, cholecystokinin; Dyn, dynorphin; Enk, enkephalin. B, Fluorescence images of a biocytin-filled NG cell, visualized with AMCA-conjugated avidin and double labeled with an antibody against $\alpha$-actinin-2. Scale bar, $10 \mu \mathrm{m}$. C, Fluorescence images of neurons in the SLM of hippocampal area CA1 triple labeled for $\alpha$-actinin-2, NPY, and b-NOS. Note that two neurons were $\alpha$-actinin-2 and b-NOS double labeled, whereas only one was triple labeled for all three markers. Scale bar, $20 \mu \mathrm{m}$. D, Graphical representation of the cumulative percentage of SLM cells double or triple labeled for NPY, $\alpha$-actinin-2, and b-NOS. One hundred percent represents the total number of cells labeled for each molecule, and this number is indicated above each column.

molecule (Table 2). None of the NG cells were positive for parvalbumin or vasoactive intestinal peptide. The other markers were expressed only in a few NG cells or non-NG interneurons in a comparable proportion. For example, b-NOS was detected in 7 of 15 NG cells and in 7 of 11 non-NG cells. To verify this result using immunocytochemistry, sections containing biocytin-filled NG cells were used in double-labeling experiments. Unfortunately, NPY immunoreactivity was not reliably detected in sections derived from in vitro incubated slices (data not shown). It has been reported that NPY-expressing neurons in the SLM of area CA1 coexpress the actin-binding protein $\alpha$-actinin-2 (Ratzliff and Soltesz, 2001). Therefore, we tested for the expression of this molecule in our recorded neurons. In 10 of 14 biocytin-filled NG cells, $\alpha$-actinin-2 expression was observed (Fig. $2 B$ ). Cells used for $\alpha$-actinin-2 labeling came from paired recordings and possessed electrophysiological properties characteristic of NG pairs (see below). Immunocytochemical experiments were also performed using perfusion-fixed brain tissue. Both molecules were detectable in the SLM, with $81 \%$ of NPY-positive neurons double labeled for $\alpha$-actinin-2 (Fig. 2C,D) $(n=32)$. Furthermore, we also tested for b-NOS immunoreactivity (Fig. $2 C, D)(n=40)$ and 
Table 2. Multiplexed PCR results for anatomically characterized SLM interneurons

\begin{tabular}{|c|c|c|c|c|c|c|c|c|c|c|c|c|}
\hline & GAD 65 & GAD 67 & $\mathrm{CaB}$ & $C R$ & PV & CCK & NPY & SOM & VIP & DYN & Enk & b-NOS \\
\hline \multicolumn{13}{|l|}{ NG cells } \\
\hline $0405-1$ & $y$ & $y$ & $y$ & $y$ & $\mathrm{n}$ & $y$ & $y$ & $y$ & $n$ & $n$ & $y$ & $y$ \\
\hline $0407-3$ & $y$ & $y$ & $\mathrm{n}$ & $\mathrm{n}$ & $n$ & $n$ & $y$ & $n$ & $n$ & $n$ & $n$ & $n$ \\
\hline 0407-4 & $y$ & $y$ & $\mathrm{n}$ & $\mathrm{n}$ & $\mathrm{n}$ & $y$ & $y$ & $y$ & $\mathrm{n}$ & $n$ & $y$ & $y$ \\
\hline $0407-5$ & $y$ & $y$ & $n$ & $\mathrm{n}$ & $\mathrm{n}$ & $n$ & $n$ & $n$ & $n$ & $n$ & $y$ & $n$ \\
\hline 0408-1 & $y$ & $y$ & $\mathrm{n}$ & $y$ & $n$ & $n$ & $y$ & $\mathrm{n}$ & $n$ & $n$ & $n$ & $\mathrm{n}$ \\
\hline $0408-2$ & $y$ & $y$ & $y$ & $n$ & $n$ & $n$ & $y$ & $n$ & $n$ & $n$ & $n$ & $y$ \\
\hline $0408-4$ & $y$ & $y$ & $y$ & $y$ & $\mathrm{n}$ & $y$ & $y$ & $\mathrm{n}$ & $n$ & $y$ & $\mathrm{n}$ & $n$ \\
\hline $0408-5$ & $y$ & $y$ & $n$ & $n$ & $n$ & $n$ & $y$ & $\mathrm{n}$ & $n$ & $n$ & $\mathrm{n}$ & $\mathrm{n}$ \\
\hline 0413-4 & $y$ & y & $\mathrm{n}$ & $y$ & $n$ & $y$ & y & $y$ & $n$ & $n$ & $n$ & $y$ \\
\hline $0419-2$ & $y$ & $y$ & $\mathrm{n}$ & $\mathrm{n}$ & $\mathrm{n}$ & $n$ & $y$ & $y$ & $n$ & $\mathrm{n}$ & $n$ & $n$ \\
\hline 0419-3 & $y$ & $y$ & $\mathrm{n}$ & $\mathrm{n}$ & $n$ & $n$ & $y$ & $n$ & $n$ & $n$ & $n$ & $y$ \\
\hline 0420-4 & $y$ & $y$ & $\mathrm{n}$ & $\mathrm{n}$ & $\mathrm{n}$ & $y$ & $n$ & $n$ & $n$ & $n$ & $n$ & $y$ \\
\hline 0518-1 & $y$ & $y$ & $\mathrm{n}$ & $\mathrm{n}$ & $n$ & $n$ & $n$ & $n$ & $n$ & $n$ & $n$ & $n$ \\
\hline $0518-2$ & $y$ & $y$ & $\mathrm{n}$ & $y$ & $n$ & $y$ & $y$ & $\mathrm{n}$ & $n$ & $n$ & $y$ & $y$ \\
\hline $0525-3$ & $y$ & $y$ & $\mathrm{n}$ & $n$ & $\mathrm{n}$ & $n$ & $y$ & $\mathrm{n}$ & $\mathrm{n}$ & $\mathrm{n}$ & $n$ & $n$ \\
\hline Total & 15 & 15 & 3 & 5 & 0 & 6 & 12 & 4 & 0 & 1 & 4 & 7 \\
\hline \multicolumn{13}{|c|}{ Non-NG cells } \\
\hline 0407-1 & $y$ & $y$ & $\mathrm{n}$ & $\mathrm{n}$ & $n$ & $n$ & $y$ & $y$ & $\mathrm{n}$ & $\mathrm{n}$ & $y$ & $y$ \\
\hline 0407-6 & $y$ & $y$ & $\mathrm{n}$ & $y$ & $n$ & $y$ & $n$ & $n$ & $n$ & $n$ & $y$ & $y$ \\
\hline $0413-2$ & $y$ & $y$ & $n$ & $n$ & $\mathrm{n}$ & $n$ & $n$ & $n$ & $n$ & $n$ & $y$ & $n$ \\
\hline 0413-6 & $y$ & y & $n$ & $y$ & $\mathrm{n}$ & $y$ & $n$ & $n$ & $n$ & $n$ & $n$ & $y$ \\
\hline $0420-5$ & $y$ & $y$ & $y$ & $n$ & $y$ & $n$ & $n$ & $y$ & $n$ & $n$ & $y$ & $n$ \\
\hline 0517-1 & $y$ & $y$ & $n$ & $\mathrm{n}$ & $n$ & $n$ & $y$ & $n$ & $n$ & $n$ & $y$ & $y$ \\
\hline 0517-2 & $y$ & y & $y$ & $y$ & $n$ & $y$ & $n$ & $y$ & $n$ & $n$ & $y$ & $n$ \\
\hline $0517-3$ & $y$ & $y$ & $y$ & $n$ & $n$ & $y$ & $n$ & $n$ & & $n$ & $n$ & $y$ \\
\hline $0518-3$ & $y$ & $y$ & $n$ & $y$ & $\mathrm{n}$ & $y$ & $n$ & $y$ & $n$ & $\mathrm{n}$ & $y$ & $y$ \\
\hline 0518-4 & $y$ & $y$ & $y$ & $n$ & $\mathrm{n}$ & $y$ & $\mathrm{n}$ & $y$ & $\mathrm{n}$ & $\mathrm{n}$ & $y$ & $y$ \\
\hline 0525-1 & $y$ & $y$ & $n$ & $\mathrm{n}$ & $\mathrm{n}$ & $n$ & $n$ & $n$ & $n$ & $n$ & $n$ & $n$ \\
\hline Total & 11 & 11 & 4 & 4 & 1 & 6 & 2 & 5 & 0 & 0 & 8 & 7 \\
\hline
\end{tabular}

y, Yes; n, no; GAD 65 and 67, glutamic acid decarboxylases 65 and 67; CaB, calbindin; PV, parvalbumin; CR, calretinin; VIP, vasointestinal peptide; SOM, somatostatin; CCK, cholecystokinin; Dyn, dynorphin; Enk, enkephalin.

found that $46 \%$ of $\alpha$-actinin-2-immunoreactive neurons were positive for b-NOS. Consistent with the single-cell RT-PCR results, 50\% of NPY-positive neurons in the SLM were immunoreactive for b-NOS, supporting the validity of the single-cell RTPCR method to accurately predict the expression patterns of proteins and peptides.

\section{Stimulation of the direct perforant pathway excites NG neurons}

Current-clamp recordings from NG cells (Fig. $3 A$ ) revealed these neurons have low input resistances $(215.3 \pm 92.8 \mathrm{M} \Omega ; n=32)$, a mean membrane time constant of $12.43 \pm 4.59 \mathrm{~ms}(n=32)$, and a mean resting membrane potential of $-63.1+5.6 \mathrm{mV}(n=33)$. When neurons were challenged with depolarizing current pulses to just beyond threshold, action potentials were seen to activate in a delayed manner. Action potentials were of relatively short duration $(0.9 \pm 0.18 \mathrm{~ms} ; n=26)$ and followed by a large AHP $(20.4 \pm 4.1 \mathrm{mV} ; n=34)$. Large-amplitude current pulses resulted in action potential discharges that were either continuous, showing some degree of adaptation, or interrupted by gaps to yield spike clusters (Fig. $3 A_{1}, A_{2}$ ). Maximal rates of action potential discharge averaged $52.8 \pm 31.0 \mathrm{~Hz}(n=26)$ and ranged between 7 and $122 \mathrm{~Hz}$ for a $1 \mathrm{~s}$ stimulation.

To examine perforant path stimulation of SLM NG cells, we made voltage-clamp recordings of evoked synaptic responses. In nearly all neurons tested, perforant path stimulation resulted in EPSC generation that at $-70 \mathrm{mV}$ was completely inhibited by treatment with the ionotropic glutamate receptor antagonist DNQX $(20 \mu \mathrm{M})$ (Fig. $3 B$ ) in the presence of $50 \mu \mathrm{M}$ picrotoxin. To assess the monosynaptic nature of this input, measurements of the synaptic jitter were performed (Doyle and Andresen, 2001). For nine NG cells tested, the latency was short ( $5.0 \pm 1.5 \mathrm{~ms})$ and clearly unimodal with a small jitter $(268 \pm 92 \mu \mathrm{s})$ (Fig. $\left.3 B_{1}\right)$. However, for 11 other neurons analyzed, frequency histograms for latencies had two or more peaks (Fig. $3 B_{2}$ ). Rather than representing a polysynaptic input, this likely represents separate monosynaptic inputs being activated, because the mean jitter around the first peak and around the second peak was $231 \pm 72$ $\mu \mathrm{s}$ and $271 \pm 88 \mu \mathrm{s}$, respectively. Consistent with this interpretation, we also found that NMDA-mediated EPSCs, recorded at $+40 \mathrm{mV}$ and in the presence of $20 \mu \mathrm{M} \operatorname{DNQX}(n=5)$ (Fig. $3 C$ ), had similar latency distributions to those seen for AMPA receptor-mediated EPSCs recorded in the same cells at $-70 \mathrm{mV}$ (Fig. $3 C_{1}, 3 C_{2}$ ).

In vivo, entorhinal-hippocampal circuits display activity at theta and gamma frequency ranges (Chrobak et al., 2000). Therefore, to further explore the nature of the perforant path input onto NG cells, higher frequency stimulation was used. When stimulated at $40 \mathrm{~Hz}$, two distinct patterns of response were observed. Some NG cells possessed a depressing synapse, in which the amplitude of EPSCs decreased immediately after the first stimuli $(n=15)$ (Fig. $\left.4 A_{1}\right)$. Alternatively, synapses showed a facilitating/depressing pattern in which depression of EPSC amplitude did not immediately occur after the first stimulus $(n=$ 20) (Fig. $4 A_{2}$ ). These two patterns of short-term plasticity were significantly different (two-way ANOVA) (Fig. $4 A_{3}$ ). A number of passive and active membrane properties of NG cells were compared between these two groups of cells (Fig. 4B). Although the mean membrane potential and AHP amplitude did not differ ( $p=0.19$ and 0.99 , respectively), significant differences were 


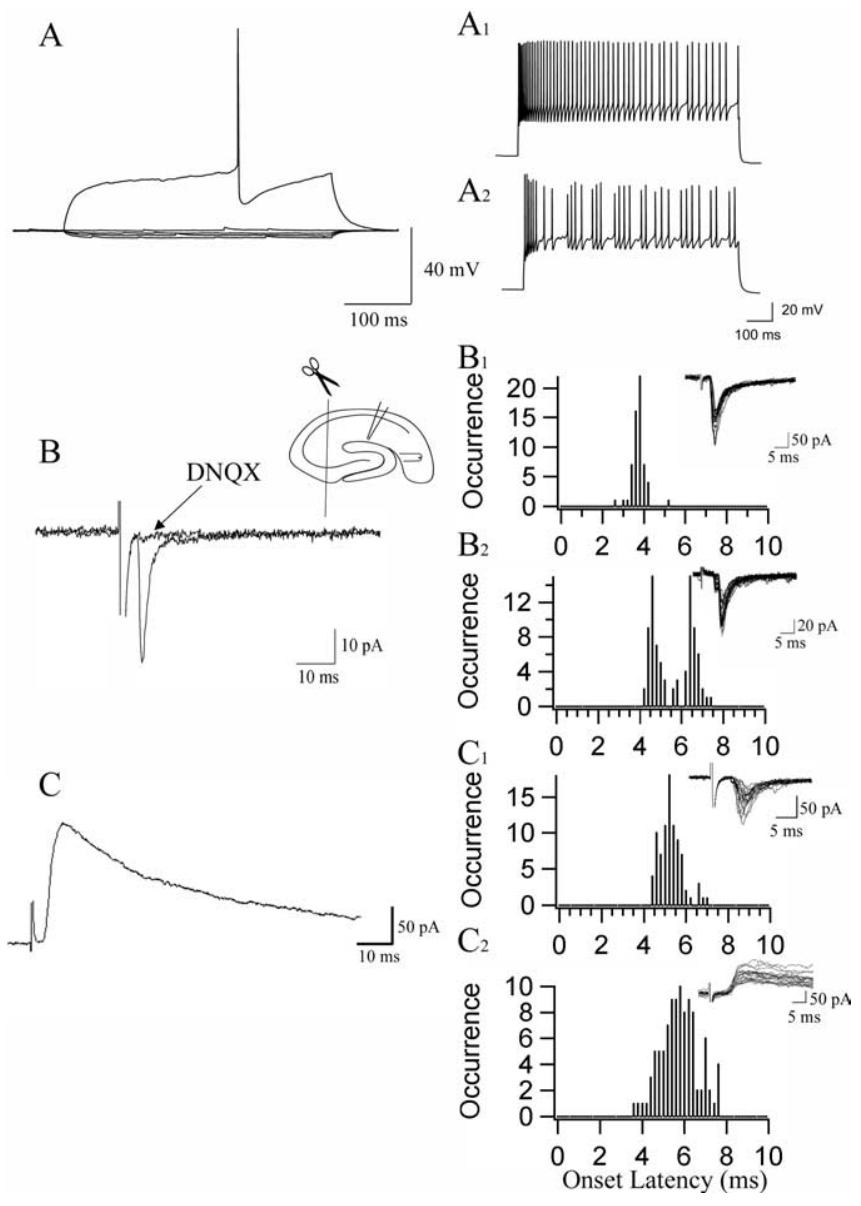

Figure 3. Electrophysiological characterization and perforant path-evoked excitability of NG cells. $A$, Current-clamp traces showing the results of hyperpolarizing current-clamp steps of 10 , 20 , and $30 \mathrm{pA}$ demonstrate the low input resistance associated with NG cells, whereas a depolarizing current step (220 pA) to just beyond threshold shows the slow ramping of membrane voltage just before action potential initiation. Large depolarizing current steps, 700 and $500 \mathrm{pA}$, respectively, elicit weak accommodating spike trains $\left(\boldsymbol{A}_{\mathbf{1}}\right)$ and bursting spike trains $\left(\boldsymbol{A}_{2}\right) . \boldsymbol{B}$, Voltage-clamp recordings show the effect of stimulation of the perforant path from the entorhinal cortex. Short-latency, fast EPSCS were generated in NG cells and were abolished by bath application of $20 \mu \mathrm{m}$ DNQX. The inset shows the position of stimulating and recording electrodes and the location of the cut made to excise area $C A 3$. Traces are the average 10 sweeps. $\boldsymbol{B}_{1}$, Frequency histograms illustrating a unimodal distribution of EPSCs generated by perforant path stimulation ( $n=60$ events analyzed; $n=20$ traces shown superimposed). $\boldsymbol{B}_{2}$, The distribution of onset times was clearly bimodal in a different neuron. The insets show voltage-clamp traces from which data in histograms were obtained ( $n=84$ events analyzed; $n=20$ traces shown superimposed). C, NMDA receptor-dependent EPSC recorded at a holding potential of $+40 \mathrm{mV}$ in the presence of $20 \mu \mathrm{m}$ DNQX. In the electrode solution, potassium gluconate was substituted with cesium methansulphonate. Traces are the average 10 sweeps. $\boldsymbol{C}_{1}$, The distribution of onset times of control EPSCs recorded at $-70 \mathrm{mV}$ ( $n=85$ events analyzed; $n=20$ traces shown superimposed). $C_{2}$, From the same neuron, the distribution of onset times for NMDA receptormediated EPSCs recorded at $+40 \mathrm{mV}$ and in the presence of $20 \mu \mathrm{m}$ DNQX. Note that a similar range of onset times was present for the evoked responses recorded under either condition ( $n=99$ events analyzed; $n=20$ traces shown superimposed).

observed in action potential half-width, membrane time constant, and input resistance ( $p<0.01$ for each variable). Interestingly, statistical analysis of the mean postnatal age of the animals showed that a significantly greater proportion of NG cells from younger animals possessed depressing-type excitatory inputs (Mann-Whitney test; $p<0.05 ; n=35$ ) (Fig. $4 C_{1}$ ), suggesting a developmental factor underlying this result, despite a short stellate dendritic arbor and a dense axonal arbor typical of NG cells being present in neurons that showed either pattern of short-
$\mathrm{A}_{1}$

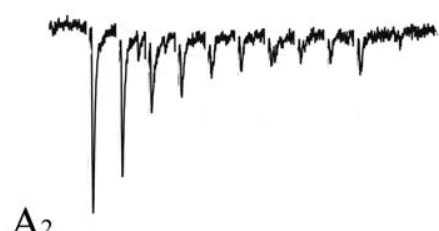

$\mathrm{B}_{1}$

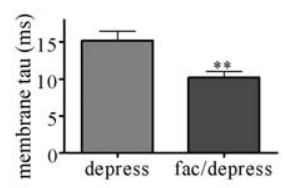

$\mathrm{B}_{2}$
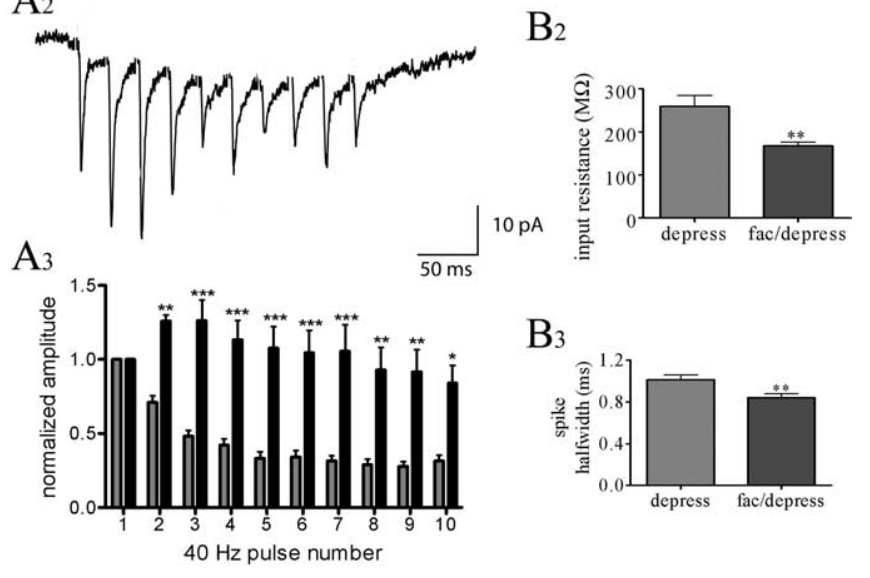

$\mathrm{B}_{3}$

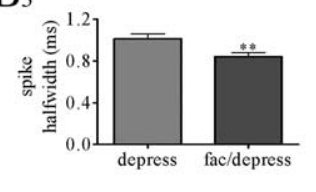

$\mathrm{C}_{1}$
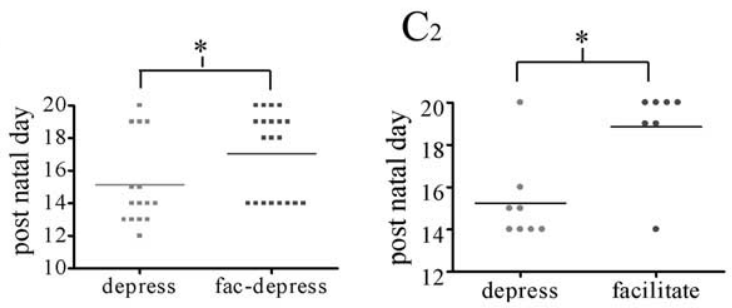

Figure 4. Short-term plasticity of perforant path inputs onto NG cells. $A_{1}$, Voltage-clamp trace of the response of an NG cell to $40 \mathrm{~Hz}$ stimulation with a train of EPSCs that depressed rapidly. $A_{2}$, Recording from a second NG cell that showed initial facilitation, followed by depression after a $40 \mathrm{~Hz}$ stimulation. Associated with the facilitation was a slowly developing inward shift in baseline, likely reflecting the summation of EPSCs at high stimulus frequency. Each trace represents the average of 10 sweeps. $A_{3}$, Summary graph illustrating the EPSC peak amplitudes during a $40 \mathrm{~Hz}$ stimulation normalized to the first EPSC (ANOVA; Bonferroni's post hoc values: ${ }^{*} p<0.05,{ }^{* *} p<0.01$, and $\left.{ }^{* * *} p<0.001\right)$. Gray bars, Depressing pattern; black bars, facilitating/depressing pattern. $\boldsymbol{B}$, Histograms comparing membrane time constant (tau; $\left.\boldsymbol{B}_{1}\right)$, input resistance $\left(\boldsymbol{B}_{2}\right)$, and action potential (spike) half-width $\left(\boldsymbol{B}_{3}\right)$ for NG cells showing either depressing (depress) or facilitating (fac)/depressing forms of short-term plasticity. $\boldsymbol{C}$, Scatter dot plots illustrating the postnatal age for each cell displaying either depressing or facilitating/depressing short-term plasticity in response to a $40 \mathrm{~Hz}\left(\boldsymbol{C}_{\mathbf{1}}\right)$ or $10 \mathrm{~Hz}\left(\boldsymbol{C}_{2}\right)$ stimulation. The line represents the mean for each group.

term plasticity (Fig. 1A,B). Furthermore, input resistance and membrane time constant, but not action potential half-width, were significantly greater in younger than older animals ( $t$ test; $p<0.05$ and $p<0.0001$, respectively). A similar relationship, with younger animals showing synaptic depression, was observed when perforant path afferents were stimulated at $10 \mathrm{~Hz}$, with the exception that facilitation tended to be maintained through the duration of a $10 \mathrm{~Hz}$ train stimulation (Mann-Whitney test; $p<$ $0.05 ; n=15)\left(\right.$ Fig. $\left.4 C_{2}\right)$.

\section{CA1 NG cells respond to Schaffer collateral stimulation}

To investigate the influence of other excitatory pathways on to CA1 NG cells, we also tested whether Schaffer collateral (SC) stimulation evoked any response in neurons recorded from hippocampal slices without excision of CA3. In all nine NG cells tested, stimulation near the CA3 pyramidal cell layer resulted in evoked EPSCs (Fig. 5A). The mean onset time for the EPSCs was 

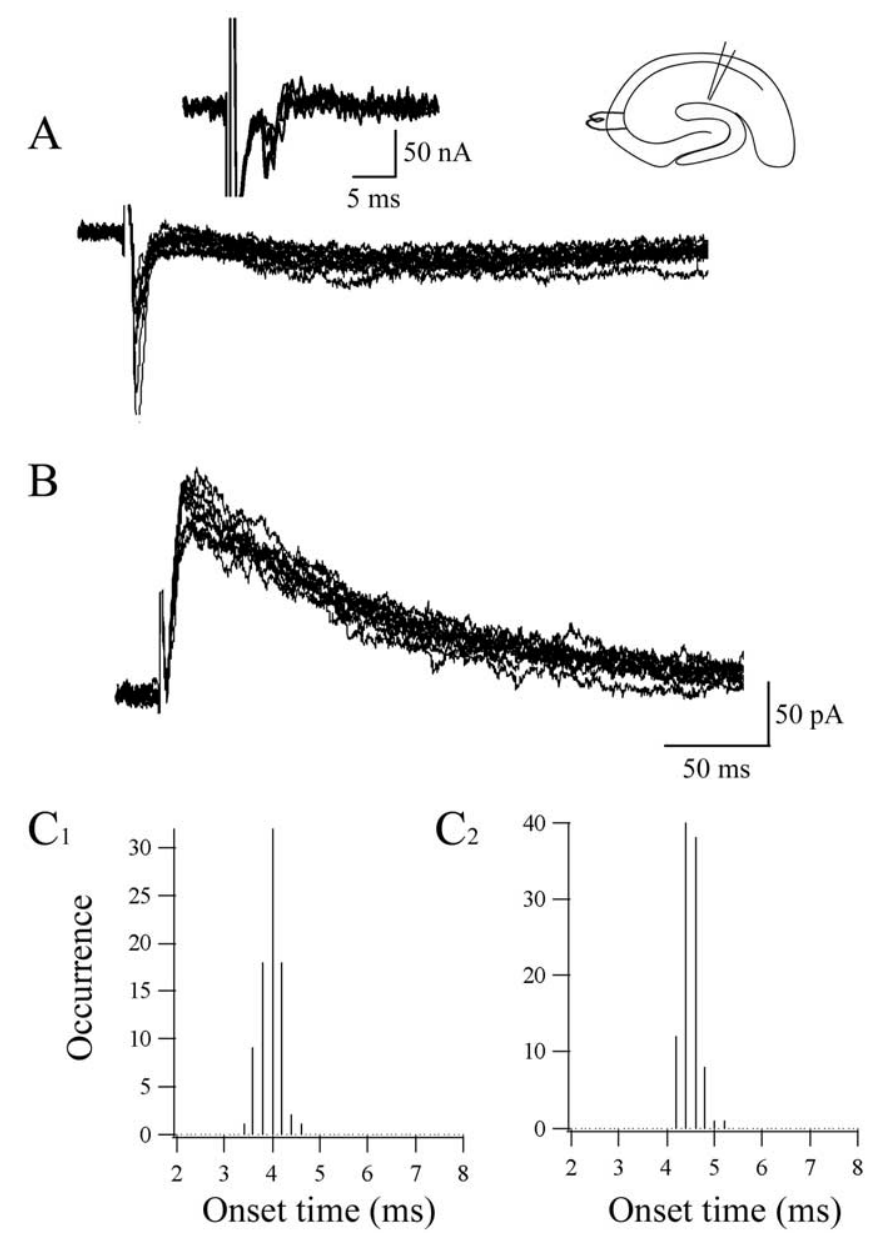

Figure 5. SC stimulation monosynaptically excites NG cells. A, SC stimulation evokes EPSCS with a short and constant latency in voltage-clamped NG cells. The left inset shows the differentiated traces illustrating onset latency; the right inset depicts the position of recording and stimulating electrodes. $\boldsymbol{B}$, Under conditions favoring the recording of NMDA currents $(20 \mu \mathrm{M}$ DNQX; holding potential, $+40 \mathrm{mV}$ ), monosynaptic EPS(s were also evoked in the same neuron. For each panel, 10 superimposed sweeps are shown. Onset latency distributions for both AMPAmediated $\left(\boldsymbol{C}_{1}\right)$ and NMDA-mediated $\left(\boldsymbol{C}_{2}\right)$ EPSCs were similar, confirming that the glutamatergic input from the SCs onto this cell was monosynaptic.

$7.56 \pm 2.85 \mathrm{~ms}$, with a mean jitter of $258.4 \pm 111.9 \mu \mathrm{s}$. In two neurons occurring later, likely polysynaptic EPSCs were also observed that had higher jitter values (1922 and $3087 \mu$ s). Furthermore, NMDA-mediated EPSCs, isolated in $20 \mu \mathrm{M}$ DNQX and recorded at $+40 \mathrm{mV}$ (Fig. $5 B$ ), displayed latency distributions similar to those observed for AMPA-mediated EPSCs evoked at $-70 \mathrm{mV}$ (Fig. $\left.5 C_{1}, C_{2}\right)(n=4)$. As with perforant path stimulation, both depressing $(n=2)$ and facilitating/depressing $(n=1)$ patterns of synaptic activation were observed in NG cells after a $40 \mathrm{~Hz}$ stimulation (data not shown).

\section{NG cells form an electrically and chemically connected network}

Next, we performed paired recordings between adjacent NG cells and between NG cells and other interneurons of the CA1 SLM. In $85 \%$ of recordings between pairs of NG cells, some form of synaptic communication occurred, either electrical only $(17 \%)$ or mixed electrical and chemical (83\%) (Fig. 6A). In pairs in which chemical synapses were present, these were not always reciprocal, such that stimulation of one cell of the pair resulted in an IPSC, whereas stimulation of the other cell did not result in an IPSC

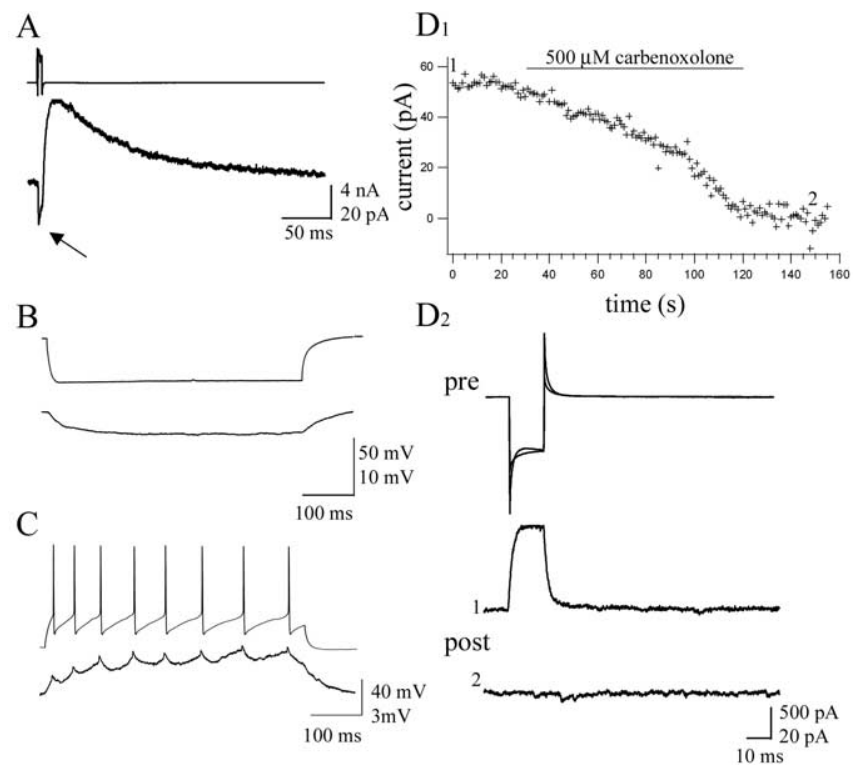

Figure 6. Mixed electrical and chemical synapses between pairs of NG cells. $\boldsymbol{A}$, Unitary IPSCS recorded in voltage clamp (bottom trace) evoked by an action current in the presynaptic neuron (top trace). The arrow points to the initial inward current flowing through the electrical synapse, which was then followed by an outward current with slow decay kinetics. $\boldsymbol{B}$, Current-clamp recording showing the voltage deflection seen in the prejunctional neuron after injection of 250 $\mathrm{pA}$ of hyperpolarizing current (top) and the subsequent deflection seen in the postjunctional neuron (bottom). C, Current-clamp recording in which 190 pA of depolarizing current was injected into the prejunctional neuron to induce spiking activity (top). In the postjunctional neuron, smaller amplitude spikelets, followed by AHPs, were observed. $\boldsymbol{D}_{\boldsymbol{1}}$, Results of a voltageclamp experiment charting the time course of inhibition after application of $500 \mu \mathrm{m}$ carbenoxolone. $\boldsymbol{D}_{2}$, Top traces superimposed show the currents evoked by hyperpolarizing voltage steps from -70 to $-130 \mathrm{mV}$ in the prejunctional cell before and after application of carbenoxolone. The middle and bottom traces are the postjunctional responses before (1) and after (2) carbenoxolone. Traces are the average of 10 individual sweeps.

being generated. However, electrical synapses, as expected, were always reciprocal.

In current-clamp recordings, electrical synaptic connections were quantified via the injection of hyperpolarizing current into one of the neurons and recording the hyperpolarization induced in the second cell (Fig. 6B). The coupling coefficients obtained averaged $9.04 \pm 5.65 \%$ and ranged from 1.7 to $25.4 \%(n=24)$. Injection of depolarizing current into one neuron to evoke action potentials resulted in spikelets, followed by prominent AHPs being recorded in the second neuron (Fig. 6C). To confirm that gap junctions were indeed responsible for this observed coupling, pairs of NG cells were exposed to the gap junction blocker carbenoxolone $(500 \mu \mathrm{M})$, which resulted in the complete loss of electrical coupling $(n=4)$ (Fig. $\left.6 D_{1}, D_{2}\right)$.

Subthreshold membrane oscillations generated and maintained through electrical and chemical connections are commonly found in the cortex (Tamas et al., 2000; Blatow et al., 2003). We tested whether sinusoidal waveforms could be faithfully transmitted through pairs of NG cells. Sinusoidal waveforms of 7, 20,40, and $100 \mathrm{~Hz}$ were injected into one cell during current-clamp recordings, and the response was recorded in the second cell (Fig. 7A). With the exception of $100 \mathrm{~Hz}$ waveforms, postjunctional oscillations could be recorded. Analysis of the coupling coefficient between prejunctional and postjunctional neurons during oscillations revealed that with a frequency of 7 $\mathrm{Hz}$, there was no significant difference between the coupling coefficient measured during the oscillation and that measured with a hyperpolarizing current pulse (two-way paired $t$ test; $p>0.5$; 
$n=7)$. However, with higher oscillation frequency, the observed coupling coefficient decreased (Fig. 7B). This decrease was significant for comparisons between 7 and $20 \mathrm{~Hz}$ and between 20 and $40 \mathrm{~Hz}$ (twotailed paired $t$ test; $p<0.05 ; n=8$ and 6 , respectively). Analysis of the phase relationship between prejunctional and postjunctional cells revealed a marked angular shift in the oscillatory phase seen with all frequencies tested, which increased with higher frequencies (KruskalWallis test with Dunn post hoc test; $p<$ 0.001) (Fig. 7C).

Network relationships can also take the form of increased synchrony between electrically coupled neurons. To examine this aspect, we analyzed pairs of coupled NG cells for synchronization of spiking activity when both neurons were depolarized to beyond threshold. Cross-correlation analysis revealed that some synchrony in spiking activity was observed and that there was a significant positive correlation between the cross-correlation value and coupling coefficients (Pearson $r=0.845$; $p<$ 0.05 ) (Fig. $7 D, E$ ).

The amplitude of unitary IPSCs recorded between NG cells was, on average, $20.97+23.68 \mathrm{pA}(n=27)$, was inhibited in the presence of either $30 \mu \mathrm{M}$ bicuculline or $10 \mathrm{~mm}$ SR 95531 (Fig. $\left.8 D_{1}\right)(n=2$ and 12 , respectively), and possessed several characteristics that were common to all recordings (Fig. 6A). First, unitary IPSCs had a slow time course of decay that was well fit with a single exponential and had an off rate constant of $42.05 \pm 21.03 \mathrm{~ms}$ $(n=23)$. Second, the unitary IPSCs were very sensitive to the rate at which presynaptic action potentials were elicited, whereby stable IPSC amplitude was observed if the rate of stimulation did not exceed about one per $60 \mathrm{~s}$. When the presynaptic neuron was stimulated in the theta range at $5 \mathrm{~Hz}$, the resulting postsyn-

aptic response was strongly depressing (Fig. 8A). Interestingly, this depression was greatly inhibited by the application of the $\mathrm{GABA}_{\mathrm{B}}$ receptor antagonist CGP55845 $(5 \mu \mathrm{M} ; n=20)($ Fig. $8 B)$, whereas IPSCs were almost completely blocked with 20-30 $\mu \mathrm{M}$ baclofen, which also activated an outward current in the recorded neurons (data not shown; $n=6$ ). The inhibition of depression by CGP55845 was not significantly different under recording conditions in which cesium methansulphonate substituted for potassium gluconate in the electrode solution for the postsynaptic neuron, to block the potential activation of potassium conductances by $\mathrm{GABA}_{\mathrm{B}}$ receptors in the postsynaptic cell $(n=3 ; p>$ 0.5 ). This supports the idea that presynaptic $\mathrm{GABA}_{\mathrm{B}}$ autoreceptors were mediating the depression seen with theta stimulation. The first pulse also showed a significant increase in amplitude, indicative of a tonic level of $\mathrm{GABA}_{\mathrm{B}}$ receptor activation (Fig. $8 C_{1}, C_{2}$ ) (paired $t$ test; $p<0.01 ; n=14$ ). An endogenous activation of $\mathrm{GABA}_{\mathrm{B}}$ receptors could also be detected during paired
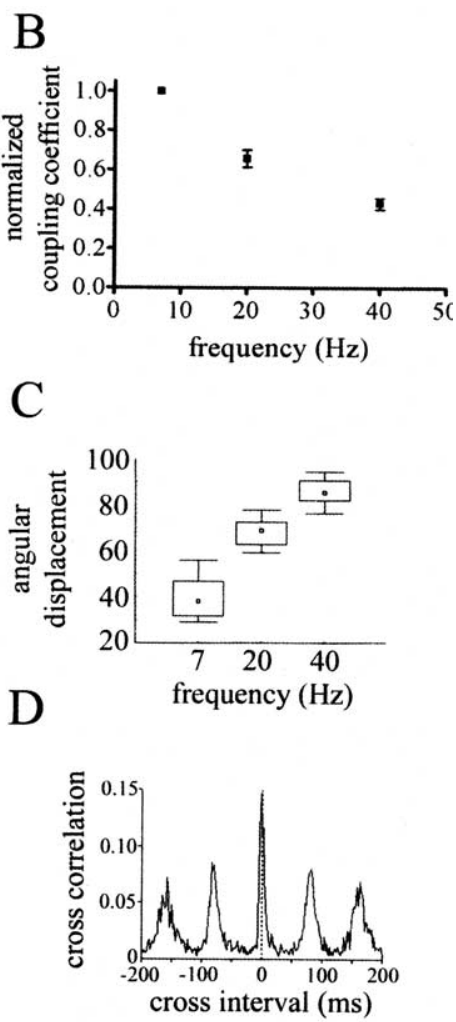

$\mathrm{E}$

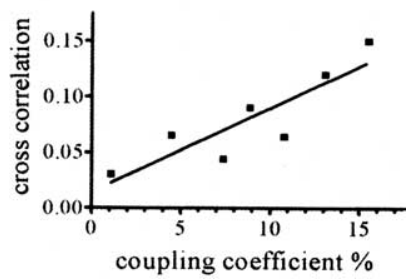

Figure 7. Oscillations and synchronous behavior of electrically coupled NG cells. $A$, Current-clamp recordings of 7, 20, and $40 \mathrm{~Hz}$ sine waves injected into the prejunctional neuron and the resulting attenuated postjunctional potential. Each record is the of 10 traces obtained at each frequency. The inset is an expanded trace for the first oscillation at $7 \mathrm{~Hz}$ to note the phas

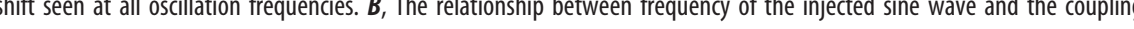
Median values are shown; the box represents the 25 and $75 \%$ intervals, whereas the minimum and maximum values are ad to construct cross-correlograms was $5 \mathrm{~ms}$. $\boldsymbol{E}$, The relationship between the coupling coefficient, measured with injection of $200 \mathrm{~ms}$

recording experiments, whereby in the presence of the $\mathrm{GABA}_{\mathrm{A}}$ antagonist SR95531 (10 $\mu \mathrm{M})$, a small unitary IPSC with slow kinetics was recorded in 7 of 11 postsynaptic NG cells (holding potential, $-40 \mathrm{mV}$ ) that was abolished by $5 \mu \mathrm{M}$ CGP55845 (Fig. 8E).

Our electrophysiological experiments suggest that $\mathrm{GABA}_{\mathrm{B}}$ receptors are present on presynaptic and postsynaptic membranes at synapses between NG cells. Therefore, we undertook an examination of the distribution of $\mathrm{GABA}_{\mathrm{B}}$ receptor subunits at symmetrical, putative GABAergic synaptic profiles in the SLM of area CA1 involving biocytin-filled NG cells. Immunoparticles for the $\mathrm{GABA}_{\mathrm{B} 1}$ protein were found on the plasma membrane of both presynaptic and postsynaptic profiles of NG cells (Fig. 9A,B). Extrasynaptic labeling was also found at sites away from active zones and postsynaptic densities. The pre-embedding method used prevented quantification of the number of particles detected. $\mathrm{GABA}_{\mathrm{B} 1}$ immunoparticles were also found, showing a 
A

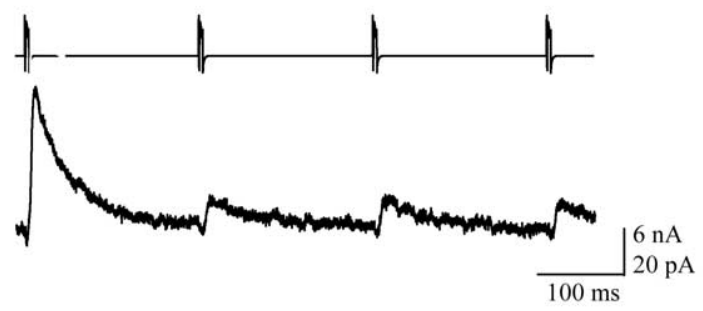

B

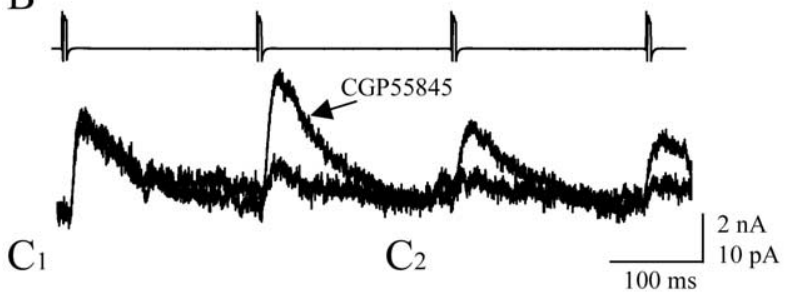

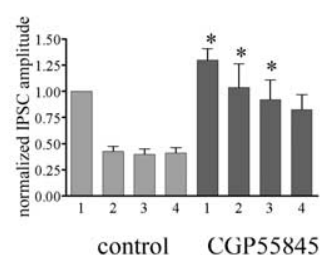

D

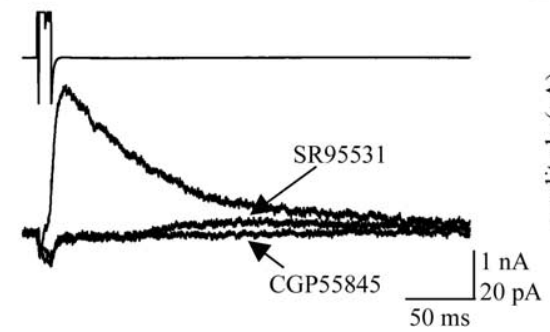

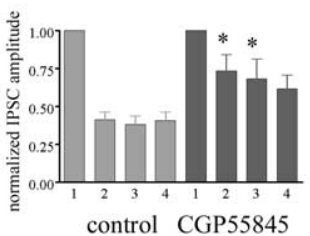

$\mathrm{E}$
Figure 8. Involvement of the $\mathrm{GABA}_{\mathrm{B}}$ receptor in the unitary IPSCs observed in NG pairs. $\boldsymbol{A}$, Voltage-clamp recordings (top trace, presynaptic action currents; bottom trace, postsynaptic unitary IPSCs) from a pair of NG cells showing the marked depression of the GABAergic IPSC seen in the postsynaptic neuron with a $5 \mathrm{~Hz}$ stimulation. $\boldsymbol{B}$, Voltage-clamp recordings (top trace, presynaptic action currents; bottom traces, postsynaptic unitary IPS(s) from a different NG cell pair showing that $5 \mu \mathrm{m}$ CGP55845 inhibits the depression seen with $5 \mathrm{~Hz}$ stimulation. $\boldsymbol{C}_{\boldsymbol{1}}$, Histogram representing the amplitude of each of the four IPSCs recorded during each $5 \mathrm{~Hz}$ train under control and $5 \mu \mathrm{M}$ CGP 55845 conditions normalized to the amplitude of the first control IPSC. Note the increase seen in the amplitude of the first pulse when $G A B A_{B}$ receptors are inhibited, suggesting a tonic activation of these receptors. $\boldsymbol{C}_{2}$, Normalizing the IPSCs to the first IPSC in CGP55845 emphasizes that depression was reduced with $\mathrm{GABA}_{\mathrm{B}}$ antagonist treatment. D, Unitary IPSCs in a NG cell pair (top trace, presynaptic action current; bottom traces, postsynaptic unitary IPSCS). In the presence of the $\mathrm{GABA}_{A}$ antagonist SR95531 (10 $\left.\mu \mathrm{m}\right)$, a small residual IPSC was observed that was abolished with application of the GABA $A_{B}$ antagonist CGP55845 (5 $\mu \mathrm{M})$. Each trace represents the average of 10 IPSCS. $\boldsymbol{E}$, Summary graph showing the mean and range of amplitudes for synaptically evoked $G A B A_{B}$ responses between $N G$ cell pairs.

similar distribution pattern, on the biocytin-filled dendritic shafts of non-NG interneurons of the CA1 SLM (Fig. 9C).

\section{Connections with other interneuronal types}

Although the majority of paired recordings between NG cells and non-NG interneurons of the CA1 SLM did not yield any communication, in several instances $(n=6)$ NG cells made synapses onto non-NG cells, with characteristic slow kinetics (Fig. $10 A)\left(\mathrm{t}_{\text {decay }}=37.4 \pm 11.86 \mathrm{~ms} ; n=3\right)$. In addition, recordings have also revealed connections between presynaptic non-NG cells and postsynaptic NG cells. Interestingly, in this case, the stimulation of the non-NG interneuron resulted in IP-
SCs with significantly faster kinetics $\left(\mathrm{t}_{\text {decay }}=10.17 \pm 6.62 \mathrm{~ms}\right.$; $n=3 ; t$ test; $p<0.05$ ) being recorded in the NG cells, and the IPSCs did not show depression during a $5 \mathrm{~Hz}$ stimulation (Fig. $10 \mathrm{~B}, \mathrm{C})$. In all of the above situations, no electrical connection was observed between NG and non-NG interneurons. Therefore, this result indicates that the NG network not only influenced the activity of other interneurons in the SLM but also received GABAergic input from other SLM interneuron subtypes.

\section{Discussion}

We add considerably to our understanding of the functional features of the hippocampal NG cell, because previously Khazipov et al. (1995) and Vida et al. (1998) only reported the anatomy and recorded from three NG cells at the border between the SLM and the stratum radiatum. The NG cells studied here were anatomically different from other interneurons reported to date from the SLM, which include neurons with axons projecting through the stratum radiatum and possessing long dendrites (Lacaille and Schwartzkroin, 1988; Williams et al., 1994; Khazipov et al., 1995; Spruston et al., 1997; Bertrand and Lacaille, 2001). The firing pattern and the intrinsic electrophysiological properties of the SLM NG cells we observed were similar to those described previously for NG cells from the neocortex (Kawaguchi, 1995; Hestrin and Armstrong, 1996; Kawaguchi and Kubota, 1997; Tamas et al., 2003).

The identification of a reliable anatomical marker for NG cells represents a significant gap in the literature, because virtually all of the other hippocampal interneuronal types known express a specific pattern of molecular cell markers (Somogyi and Klausberger, 2005). Here, we show, using single-cell RT-PCR, that the great majority of SLM NG cells express mRNA for NPY. Unfortunately, we did not reliably detect immunologically NPY in biocytin-filled recorded neurons. Interestingly, it was reported that NPY-expressing interneurons of the SLM from colchicinetreated rats coexpressed the actin-associated protein $\alpha$-actinin-2 (Ratzliff and Soltesz, 2001). We observed that the majority of NG cells tested were immunopositive for $\alpha$-actinin-2. We also found that approximately two-thirds of neurons in the SLM that expressed $\alpha$-actinin- 2 expressed NPY in perfusion-fixed brain slices. Thus, it is likely that colocalization of these two proteins represents a reliable marker for NG cells in the hippocampus and may have functional relevance (Baraban and Tallent, 2004). NPY presynaptically inhibits excitatory synaptic transmission at the CA3-CA1 synapse (Colmers et al., 1987). Therefore, if released by NG cells, NPY may also depress the release of glutamate from perforant path terminals in the SLM. Furthermore, $\alpha$-actinin-2 enhances the open probability of the NMDA receptor channel in hippocampal granule cells (Rycroft and Gibb, 2004) and may do so also in NG cells.

\section{Excitatory inputs onto SLM NG cells}

The SLM is the primary site where axons from layer III of the entorhinal cortex terminate in area CA1 (Witter et al., 1988). This input is involved in the setting of place fields and in memory and cognitive tasks (McNaughton et al., 1989; Sybirska et al., 2000; Brun et al., 2002). Pyramidal neurons receive asymmetric synapses on their distal dendrites in the SLM from layer III afferents and fire action potentials after their activation (Yeckel and Berger, 1990). Perforant path stimulation should also excite interneurons in the SLM (Desmond et al., 1994; Kiss et al., 1996), but the physiological evidence is limited. We show that NG cells are monosynaptically activated by perforant path stimulation. The predominately SLM localization of axons for NG cells sug- 
gests that they are specialized for inhibition of the perforant path input and other interneurons in the SLM. Consistent with this, NG cells generated only weak IPSCs in NG-pyramidal cell pair recordings, indicative of synapses occurring between the two cell types on distal dendrites (Vida et al., 1998). Interestingly, the presence of axonal branches in the molecular layer of the dentate gyrus suggests NG cells exert a widespread influence in the hippocampus.

Physiologically, NG cells can be divided in two groups based on developmental maturation, despite the lack of apparent morphological heterogeneity. NG cells from younger animals displayed depressing EPSCs after high-frequency stimulation of the perforant path and also a lower membrane time constant and input resistance. In contrast, NG cells from older animals showed facilitating/depressing EPSCs and a higher membrane time constant and input resistance. Thus, both presynaptic and postsynaptic intrinsic membrane factors contribute to the functional differences detected between the two groups of NG cells. It is sometimes observed that, with maturation, synapses become facilitating, reflecting a decrease in the probability of transmitter release and a shift in the inputs to these neurons to fire at higher frequencies (Reyes and Sakmann, 1999; Thomson, 2000).

We also observed that all NG cells tested responded with monosynaptic EPSCs to SC stimulation, yet the recorded cells had their soma and dendrites in the

SLM, often nearby the hippocampal fissure. It is likely that branches of SCs penetrate into the SLM to synapse with NG cells, consistent with evidence that the SC system is quite widespread and not restricted to the stratum radiatum (Tamamaki and Nojyo, 1991).

\section{NG neuron network}

Results from our recordings from pairs of NG cells demonstrated that these neurons were coupled by both electrical and chemical synapses, and this represents a novel interneuronal network. From several recent studies, it has become clear that networks of electrically coupled interneurons are common and important elements in cortical circuitry (Connors and Long, 2004). The synchrony associated with electrical coupling between interneurons is a critical factor in generating oscillations in interneuron networks (Mann-Metzer and Yarom, 1999; Beierlein et al., 2000; Blatow et al., 2003). Furthermore, the inhibitory influence of interneurons can entrain principal cells to this rhythm (McBain and Fisahn, 2001; Szabadics et al., 2001). The electrical coupling between NG cells could be quite strong, with a mean coupling coefficient of nearly $10 \%$, which is comparable with that seen among interneurons in the thalamic reticular nucleus, cortical fast spiking and multipolar bursting interneurons, all of which have the ability to support synchronized oscillations (Galarreta and Hestrin, 1999; Gibson et al., 1999; Blatow et al., 2003; Long et al., 2004). The injection of sinusoidal waveforms into pairs of NG cells resulted in smaller postjunctional voltage deflections that were phase shifted, reflecting the low-pass filter nature of electrical synapses (Galarreta and Hestrin, 2001; Bennett and Zukin, 2004; Venance et al., 2004). Interestingly, our results indicated that waveforms at $7 \mathrm{~Hz}$ were well transmitted through the electrical synapses, with no reduction in the coupling coefficient and the smallest amount of phase shift seen. This frequency is in the theta range in which other interneurons in the SLM have been shown to oscillate, and is the dominant rhythm observed in this area (Chapman and Lacaille, 1999; Buzsaki, 2002; Whittington and Traub, 2003).

\section{$\mathrm{GABA}_{\mathrm{B}}$ modulation of chemical transmission}

Chemical transmission between NG cells had several characteristic features. First, it fatigued with repeated activation, necessitating the use of long interpulse intervals, a feature shared with cortical NG cells (Tamas et al., 2003). Second, IPSCs were kinetically slow, perhaps because of either the subunit composition of the $\mathrm{GABA}_{\mathrm{A}}$ receptors or the slow GABA uptake (Banks et al., 1998). Moreover, chemical transmission between NG cells was strongly depressed during train stimulation. This depression was inhibited by the $\mathrm{GABA}_{\mathrm{B}}$ antagonist CGP55845. It is likely that this modulation is presynaptic, because the IPSCs occurring later in the train were enhanced relatively more than the IPSCs elicited by the first stimulus. Furthermore, this effect was observed when the postsynaptic cell was recorded with a patch pipette containing 


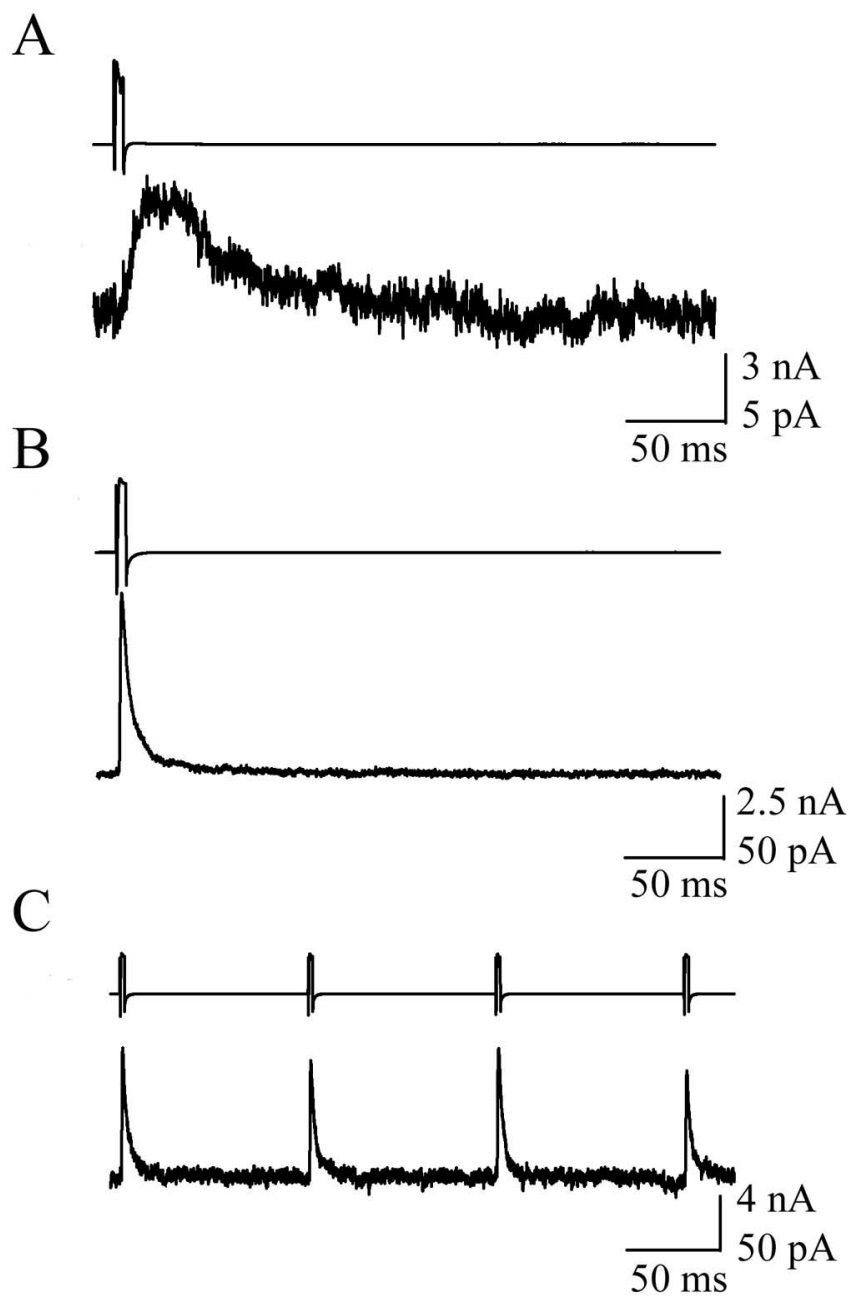

Figure 10. Synapses between NG and non-NG cells of the CA1 SLM. A, Voltage-clamp recording showing the slow IPSC recorded in a non-NG cell after NG cell stimulation. B, Stimulation of a non-NG cell resulted in a fast IPSC being recorded in the NG cell. C, Stimulation of a non- $\mathrm{NG}$ cell at $5 \mathrm{~Hz}$ resulted in a train of nondepressing IPSCs being recorded in the NG cell. The top traces illustrate presynaptic action currents, and the bottom traces illustrate unitary postsynaptic IPSCs. Each trace is the average of 10 sweeps.

cesium, to block G-protein-activated potassium conductances (Gähwiler and Brown, 1985). Interestingly, this depression was only observed when the presynaptic neuron was an NG cell, whereas nondepressing IPSCs were seen when non-NG interneurons were presynaptic. Furthermore, the unitary IPSCs were faster when the presynaptic interneuron was a non-NG cell, indicating that the identity of the presynaptic cells as a NG is an important factor contributing to the slow IPSC kinetics.

An enhancement of the peak amplitude of the first response to each $5 \mathrm{~Hz}$ train was also apparent, indicating that tonic depression mediated by $\mathrm{GABA}_{\mathrm{B}}$ receptors exists at synapses between NG cells. Our data obtained with the paired recording technique are consistent with that of Ouardouz and Lacaille (1997), obtained with minimal stimulation (but see Bertrand and Lacaille, 2001). They showed tonic $\mathrm{GABA}_{\mathrm{B}}$ presynaptic inhibition at unitary synapses between hippocampal interneurons located in the stratum oriens, near the stratum pyramidale or at the border of the stratum radiatum and SLM, and postsynaptic CA1 pyramidal neurons. Thus, this modulatory action is present whether the postsynaptic cell is a pyramidal neuron or an interneuron, lacking target specificity. We also observed a small $\mathrm{GABA}_{\mathrm{B}}$ compo- nent of the unitary IPSC, similar to that recently found by Tamas et al. (2003) at unitary IPSPs elicited by stimulation of cortical NG cells and recorded in postsynaptic pyramidal cells. This is the first time that a unitary $\mathrm{GABA}_{\mathrm{B}}$-mediated response has been detected between inhibitory GABAergic interneurons. Previously, synchronous release of GABA from a pool of interneurons was thought to be needed to activate $\mathrm{GABA}_{\mathrm{B}}$ receptors at hippocampal synapses (Scanziani, 2000). Consistent with our electrophysiological data, we did observe $\mathrm{GABA}_{\mathrm{B} 1}$ subunits on both presynaptic and postsynaptic membranes of biocytin-filled NG cells. However, the labeling of presynaptic active zones and postsynaptic sites may be underestimated because of limited accessibility of immunochemicals in the pre-embedding method.

\section{Conclusion}

Our data in vitro suggest that $\mathrm{NG}$ cells form an extensive cellular network coupled by $\mathrm{GABA}_{\mathrm{A}} / \mathrm{GABA}_{\mathrm{B}}$ receptor-mediated chemical and electrical connections with low-pass filter properties. NG cells of the CA1 SLM must play a relevant part in gating the incoming input from the entorhinal cortex into area CA1, and future work in vivo will hopefully identify specific roles and firing patterns for NG cells during network activity.

\section{References}

Amaral DG, Witter MP (1995) Hippocampal formation, Ed 2. San Diego: Academic.

Avoli M, D’Antuono M, Louvel J, Kohling R, Biagini G, Pumain R, D'Arcangelo G, Tancredi V (2002) Network and pharmacological mechanisms leading to epileptiform synchronization in the limbic system in vitro. Prog Neurobiol 68:167-207.

Banks MI, Li TB, Pearce RA (1998) The synaptic basis of GABA A slow. J Neurosci 18:1305-1317.

Baraban SC, Tallent MK (2004) Interneuron Diversity series: Interneuronal neuropeptides - endogenous regulators of neuronal excitability. Trends Neurosci 27:135-142.

Beierlein M, Gibson JR, Connors BW (2000) A network of electrically coupled interneurons drives synchronized inhibition in neocortex. Nat Neurosci 3:904-910.

Bennett MV, Zukin RS (2004) Electrical coupling and neuronal synchronization in the mammalian brain. Neuron 41:495-511.

Bertrand S, Lacaille JC (2001) Unitary synaptic currents between lacunosum-moleculare interneurones and pyramidal cells in rat hippocampus. J Physiol (Lond) 532:369-384.

Blatow M, Rozov A, Katona I, Hormuzdi SG, Meyer AH, Whittington MA, Caputi A, Monyer H (2003) A novel network of multipolar bursting interneurons generates theta frequency oscillations in neocortex. Neuron 38:805-817.

Braak H, Braak E (1993) Entorhinal-hippocampal interaction in mnestic disorders. Hippocampus 3:239-246.

Brun VH, Otnass MK, Molden S, Steffenach HA, Witter MP, Moser MB, Moser EI (2002) Place cells and place recognition maintained by direct entorhinal-hippocampal circuitry. Science 296:2243-2246.

Buzsaki G (2002) Theta oscillations in the hippocampus. Neuron 33:325-340.

Capogna M (2004) Distinct properties of presynaptic group II and III metabotropic glutamate receptor-mediated inhibition of perforant pathway-CA1 EPSCs. Eur J Neurosci 19:2847-2858.

Cauli B, Audinat E, Lambolez B, Angulo MC, Ropert N, Tsuzuki K, Hestrin S, Rossier J (1997) Molecular and physiological diversity of cortical nonpyramidal cells. J Neurosci 17:3894-3906.

Chapman CA, Lacaille JC (1999) Intrinsic theta-frequency membrane potential oscillations in hippocampal CA1 interneurons of stratum lacunosum-moleculare. J Neurophysiol 81:1296-1307.

Chrobak JJ, Lorincz A, Buzsaki G (2000) Physiological patterns in the hippocampo-entorhinal cortex system. Hippocampus 10:457-465.

Colmers WF, Lukowiak K, Pittman QJ (1987) Presynaptic action of neuropeptide $\mathrm{Y}$ in area CA1 of the rat hippocampal slice. J Physiol (Lond) 383:285-299. 
Connors BW, Long MA (2004) Electrical synapses in the mammalian brain. Annu Rev Neurosci 27:393-418.

Desmond NL, Scott CA, Jane Jr JA, Levy WB (1994) Ultrastructural identification of entorhinal cortical synapses in CA1 stratum lacunosummoleculare of the rat. Hippocampus 4:594-600.

Doyle MW, Andresen MC (2001) Reliability of monosynaptic sensory transmission in brain stem neurons in vitro. J Neurophysiol 85:2213-2223.

Empson RM, Heinemann U (1995) The perforant path projection to hippocampal area CA1 in the rat hippocampal-entorhinal cortex combined slice. J Physiol (Lond) 484:707-720.

Freund TF, Buzsaki G (1996) Interneurons of the hippocampus. Hippocampus 6:347-470.

Gähwiler BH, Brown DA (1985) $\mathrm{GABA}_{\mathrm{B}}$ receptor-activated $\mathrm{K}^{+}$current in voltage-clamped CA3 pyramidal cells in hippocampal cultures. Proc Natl Acad Sci USA 82:1558-1562.

Galarreta M, Hestrin S (1999) A network of fast-spiking cells in the neocortex connected by electrical synapses. Nature 402:72-75.

Galarreta M, Hestrin S (2001) Electrical synapses between GABA-releasing interneurons. Nat Rev Neurosci 2:425-433.

Gibson JR, Beierlein M, Connors BW (1999) Two networks of electrically coupled inhibitory neurons in neocortex. Nature 402:75-79.

Gloveli T, Schmitz D, Empson RM, Dugladze T, Heinemann U (1997) Morphological and electrophysiological characterization of layer III cells of the medial entorhinal cortex of the rat. Neuroscience 77:629-648.

Hestrin S, Armstrong WE (1996) Morphology and physiology of cortical neurons in layer I. J Neurosci 16:5290-5300.

Kawaguchi Y (1995) Physiological subgroups of nonpyramidal cells with specific morphological characteristics in layer II/III of rat frontal cortex. J Neurosci 15:2638-2655.

Kawaguchi Y, Kubota Y (1997) GABAergic cell subtypes and their synaptic connections in rat frontal cortex. Cereb Cortex 7:476-486.

Khazipov R, Congar P, Ben-Ari Y (1995) Hippocampal CA1 lacunosummoleculare interneurons: modulation of monosynaptic GABAergic IPSCs by presynaptic $\mathrm{GABA}_{\mathrm{B}}$ receptors. J Neurophysiol 74:2126-2137.

Kiss J, Buzsaki G, Morrow JS, Glantz SB, Leranth C (1996) Entorhinal cortical innervation of parvalbumin-containing neurons (basket and Chandelier cells) in the rat Ammon's horn. Hippocampus 6:239-246.

Kulik A, Nakadate K, Nyiri G, Notomi T, Malitschek B, Bettler B, Shigemoto $R$ (2002) Distinct localization of $G_{A B A}$ receptors relative to synaptic sites in the rat cerebellum and ventrobasal thalamus. Eur J Neurosci 15:291-307.

Kulik A, Vida I, Lujan R, Haas CA, Lopez-Bendito G, Shigemoto R, Frotscher M (2003) Subcellular localization of metabotropic $G_{A B A}$ receptor subunits $\mathrm{GABA}_{\mathrm{B} 1 \mathrm{a} / \mathrm{b}}$ and $\mathrm{GABA}_{\mathrm{B} 2}$ in the rat hippocampus. J Neurosci 23:11026-11035.

Lacaille JC, Schwartzkroin PA (1988) Stratum lacunosum-moleculare interneurons of hippocampal CA1 region. I. Intracellular response characteristics, synaptic responses, and morphology. J Neurosci 8:1400-1410.

Lambolez B, Audinat E, Bochet P, Crepel F, Rossier J (1992) AMPA receptor subunits expressed by single Purkinje cells. Neuron 9:247-258.

Long MA, Landisman CE, Connors BW (2004) Small clusters of electrically coupled neurons generate synchronous rhythms in the thalamic reticular nucleus. J Neurosci 24:341-349.

Maccaferri G, Lacaille JC (2003) Interneuron Diversity series: Hippocampal interneuron classifications-making things as simple as possible, not simpler. Trends Neurosci 26:564-571.

Mann-Metzer P, Yarom Y (1999) Electrotonic coupling interacts with intrinsic properties to generate synchronized activity in cerebellar networks of inhibitory interneurons. J Neurosci 19:3298-3306.

McBain CJ, Fisahn A (2001) Interneurons unbound. Nat Rev Neurosci 2:11-23.

McNaughton BL, Barnes CA, Meltzer J, Sutherland RJ (1989) Hippocampal granule cells are necessary for normal spatial learning but not for spatially-selective pyramidal cell discharge. Exp Brain Res 76:485-496.
Ouardouz M, Lacaille JC (1997) Properties of unitary IPSCs in hippocampal pyramidal cells originating from different types of interneurons in young rats. J Neurophysiol 77:1939-1949.

Ramon y Cajal S (1911) Histologie de systeme nerveux de l'Homme et des vertebres. Paris: Maloine.

Ratzliff AD, Soltesz I (2001) Differential immunoreactivity for alphaactinin-2, an $N$-methyl-D-aspartate-receptor/actin binding protein, in hippocampal interneurons. Neuroscience 103:337-349.

Remondes M, Schuman EM (2002) Direct cortical input modulates plasticity and spiking in CA1 pyramidal neurons. Nature 416:736-740.

Reyes A, Sakmann B (1999) Developmental switch in the short-term modification of unitary EPSPs evoked in layer 2/3 and layer 5 pyramidal neurons of rat neocortex. J Neurosci 19:3827-3835.

Rycroft BK, Gibb AJ (2004) Regulation of single NMDA receptor channel activity by alpha-actinin and calmodulin in rat hippocampal granule cells. J Physiol (Lond) 557:795-808.

Scanziani M (2000) GABA spillover activates postsynaptic $\mathrm{GABA}_{\mathrm{B}}$ receptors to control rhythmic hippocampal activity. Neuron 25:673-681.

Somogyi P, Klausberger T (2005) Defined types of cortical interneurone structure space and spike timing in the hippocampus. J Physiol (Lond) $562: 9-26$

Spruston N, Lubke J, Frotscher M (1997) Interneurons in the stratum lucidum of the rat hippocampus: an anatomical and electrophysiological characterization. J Comp Neurol 385:427-440.

Sybirska E, Davachi L, Goldman-Rakic PS (2000) Prominence of direct entorhinal-CA1 pathway activation in sensorimotor and cognitive tasks revealed by $2-D G$ functional mapping in nonhuman primate. J Neurosci 20:5827-5834.

Szabadics J, Lorincz A, Tamas G (2001) $\beta$ and $\gamma$ frequency synchronization by dendritic GABAergic synapses and gap junctions in a network of cortical interneurons. J Neurosci 21:5824-5831.

Tamamaki N, Nojyo Y (1991) Crossing fiber arrays in the rat hippocampus as demonstrated by three-dimensional reconstruction. J Comp Neurol 303:435-442.

Tamas G, Buhl EH, Lorincz A, Somogyi P (2000) Proximally targeted GABAergic synapses and gap junctions synchronize cortical interneurons. Nat Neurosci 3:366-371.

Tamas G, Lorincz A, Simon A, Szabadics J (2003) Identified sources and targets of slow inhibition in the neocortex. Science 299:1902-1905.

Thomson AM (2000) Facilitation, augmentation and potentiation at central synapses. Trends Neurosci 23:305-312.

Venance L, Glowinski J, Giaume C (2004) Electrical and chemical transmission between striatal GABAergic output neurones in rat brain slices. J Physiol (Lond) 559:215-230.

Vida I, Halasy K, Szinyei C, Somogyi P, Buhl EH (1998) Unitary IPSPs evoked by interneurons at the stratum radiatum-stratum lacunosummoleculare border in the CA1 area of the rat hippocampus in vitro. J Physiol (Lond) 506:755-773.

Whittington MA, Traub RD (2003) Interneuron Diversity series: inhibitory interneurons and network oscillations in vitro. Trends Neurosci 26:676-682.

Williams S, Lacaille JC (1992) $\mathrm{GABA}_{\mathrm{B}}$ receptor-mediated inhibitory postsynaptic potentials evoked by electrical stimulation and by glutamate stimulation of interneurons in stratum lacunosum-moleculare in hippocampal CA1 pyramidal cells in vitro. Synapse 11:249-258.

Williams S, Samulack DD, Beaulieu C, LaCaille JC (1994) Membrane properties and synaptic responses of interneurons located near the stratum lacunosum-moleculare/radiatum border of area CA1 in whole-cell recordings from rat hippocampal slices. J Neurophysiol 71:2217-2235.

Witter MP, Griffioen AW, Jorritsma-Byham B, Krijnen JL (1988) Entorhinal projections to the hippocampal CA1 region in the rat: an underestimated pathway. Neurosci Lett 85:193-198.

Yeckel MF, Berger TW (1990) Feedforward excitation of the hippocampus by afferents from the entorhinal cortex: redefinition of the role of the trisynaptic pathway. Proc Natl Acad Sci USA 87:5832-5836. 